\title{
DOING BUSINESS IN CHINA: \\ PARENTAL BACKGROUND AND GOVERNMENT INTERVENTION DETERMINE WHO OWNS BUSINESSES
}

\author{
Ruixue Jia \\ Xiaohuan Lan \\ Gerard Padró I Miquel \\ Working Paper 28547 \\ http://www.nber.org/papers/w28547
1050 Massachusetts Avenue
Cambridge, MA 02138
March 2021 \\ NATIONAL BUREAU OF ECONOMIC RESEARCH
}

\begin{abstract}
We are grateful to seminar participants at Brown University, MIT Sloan, the World Bank, the CfPE conference at UBC and the TED conference at Fudan University. We thank Shuo Chen and Zhikuo Liu for sharing some data. Padr i Miquel gratefully acknowledges financial support from The Whitney and Betty MacMillan Centre of International and Area Studies. The views expressed herein are those of the authors and do not necessarily reflect the views of the National Bureau of Economic Research.
\end{abstract}

NBER working papers are circulated for discussion and comment purposes. They have not been peer-reviewed or been subject to the review by the NBER Board of Directors that accompanies official NBER publications.

(C) 2021 by Ruixue Jia, Xiaohuan Lan, and Gerard Padró I Miquel. All rights reserved. Short sections of text, not to exceed two paragraphs, may be quoted without explicit permission provided that full credit, including $(\subset$ notice, is given to the source. 
Doing Business in China: Parental Background and Government Intervention Determine Who

Owns Businesses

Ruixue Jia, Xiaohuan Lan, and Gerard Padró I Miquel

NBER Working Paper No. 28547

March 2021

JEL No. D02,D72,O12,O38,O53

\begin{abstract}
While intergenerational transmission of entrepreneurship is a well-known regularity, we hypothesize that in a transition economy where the state retains an important role, those whose parents are government workers may also be more likely to become business owners. We test the hypothesis in China and show that (1) on average, both entrepreneurs and government workers have a higher likelihood of having children who own incorporated businesses and (2) In provinces where government involvement is higher, the likelihood that children of government workers (entrepreneurs) own incorporated businesses is significantly higher (lower). Our study demonstrates that the local economic business environment shapes the influence of parental background on business ownership.

Ruixue Jia

School of Global Policy and Strategy

University of California at San Diego

9500 Gilman Drive \#0519

La Jolla, CA 92093

and NBER

rxjia@ucsd.edu

Xiaohuan Lan

600 Guoquan Road

School of Economics

Shanghai, China

xhlan@fudan.edu.cn

Gerard Padró I Miquel

Departments of Economics and Political Science

Yale University

Rosenkranz Hall 335

115 Prospect Street

New Haven, CT 06520

and NBER

gerard.padroimiquel@yale.edu
\end{abstract}




\section{Introduction}

Entrepreneurship has long been regarded as one of the most important inputs in economic growth (e.g., Schumpeter 1911, Lucas 1978, Baumol 1990). For the last two decades, the literature on entrepreneurship has posited a number of environmental and individual factors that influence the choice of becoming an entrepreneur. ${ }^{1}$ One of the most robust findings in this literature is parental transmission of entrepreneurship: descendants of entrepreneurs have a much higher likelihood of being entrepreneurs themselves (see Dunn and Holtz-Eakin 2000 among many others). While the relative importance of the different channels underlying transmission of entrepreneurship is still a matter of scholarly debate, the literature has so far overlooked the possibility that the importance of parental background for entrepreneurship may be contingent on the business environment.

Meanwhile, a political economy literature has long recognized that the institutional environment shapes the business environment across countries. For instance, Baumol, Litan, and Schramm (2007) characterize countries into "good capitalism" - a mix of big-firm and entrepreneurial capitalism, and "bad capitalism" - state-guided and oligarchic capitalism; Zingales (2012) emphasizes the difference between "crony capitalism" that favors the elites and "a capitalism for the people" which allows open access to opportunities; and the World Bank publishes a yearly Doing Business Report which again highlights how the regulatory environment and state capabilities influence entrepreneurship. Since the skills, attitudes and networks needed to run successful businesses across these institutional environments are very different, the corresponding relevant parental background should also vary.

The main contribution of this paper is to show that the type of parental background that matters for doing business varies significantly with the institutional environment, more specifically with the role of government in the economy. The setting for our empirical analysis is modern China, a context with two particular features that are very useful for the analysis. First, while modern China offers space for successful entrepreneurship, as exemplified by companies such as Alibaba and Tencent, the government is still a central agent in the economy. Second, the transition towards a market economy has been geographically uneven, and currently there is a wide heterogeneity in government involvement in the economy. While some provinces have followed a bottom-up free

${ }^{1}$ We cannot provide a fair overview of the extensive literature. See the textbook of Parker (2018) for an extended discussion of the literature, where he reviews both individual determinants and macro factors influencing entrepreneurship. 
enterprise route to economic development, others have instead focused on large conglomerates and heavy government intervention. For example, Huang (2008) contrasts Shanghai, a provincial-level municipality that has championed state-led capitalism, with Zhejiang, which exemplifies bottom-up capitalism. Both of these provinces are among the most developed in China. However, there are substantially more private firms and registered patents per capita in Zhejiang than in Shanghai.

The paramount role of the government in the economy suggests that a successful business career may require access to specific knowledge about the internal workings of government as well as networks that extend into government institutions. Hence, in terms of determining one's business aptitude, having parents who work in the government (henceforth, "cadre parents") may be as important as having parents who are entrepreneurs. In fact, both types of parental links are often emphasized by observers and scholars. A report in the Financial Times in 2015 noted "lift the curtain on many a rags-to-riches story in China, and one finds a father or grandfather who was a businessman or a government official". ${ }^{2}$ Moreover, those with cadre parents should have a larger advantage in those provinces where the government is more involved in the economy. Therefore, by comparing the relative importance of entrepreneur and cadre parental background across provinces, we can infer whether the institutional environment is determining the networks and specific human capital that are necessary to run a business with the advantage of a within-country design, which keeps other potential confounders constant.

We explore these hypotheses using the Chinese General Social Survey (CGSS). This survey has two useful features. First, it asks for the profession of the respondent as well as the profession of the parents at the time the respondents were adolescents. Second, for the respondent generation it distinguishes between those who own incorporated businesses ("business owners" henceforth) and the self-employed. ${ }^{3}$ In modern China, these categories align with the distinction between transformational or opportunity entrepreneurship and subsistence or necessity entrepreneurship. While the empirical entrepreneurship literature traditionally conflated these two categories, this distinction has recently been shown to be important (e.g., Schoar 2010, Levine and Rubinstein 2017).

We first show that having entrepreneur parents is associated with a higher likelihood of both business ownership and self-employment, and the magnitude of such intergenerational transmission

${ }^{2}$ Consistent with this, while Li et al.(2008) find that political connections influence the performance of Chinese firms, and Djankov et al (2006) show that having friends and family members who are entrepreneurs is an important driver of entrepreneurship in China.

${ }^{3}$ Self-employment often denotes a low-quality business with no employees which results from lack of access to salaried jobs. 
is comparable to other countries. We then show that having cadre parents leads to a higher propensity of business ownership, but not to self-employment. When we account for the fact that descendants of cadre parents disproportionately take government jobs, the propensity of children of cadre parents to become business owners is very close and statistically indistinguishable from the propensity of the children of entrepreneurs to become business owners.

We then show that the influence of parental background on business-ownership is contingent on the government's role in the business environment. We measure it using Provincial Government Expenditure on Business-related activities over GDP, which we henceforth refer to as PGEB. This measure varies at the province-year level, can be readily obtained from statistical yearbooks, and aggregates the budgetary items that are most likely to generate transfers or payments from the government to private business. Controlling for province-year fixed effects, we show that cadre parents' propensity to have business-owner children is strongly increasing in PGEB. In contrast, higher PGEB is associated with a lower likelihood that business owners have entrepreneur parents. These differing patterns are both statistically and economically significant: one standard deviation larger PGEB is associated with a 0.8 percentage points reduction in the probability that children of entrepreneurs are business owners and a 0.5 percentage point increase in the probability that children of cadres are business owners. These are very large effects since the average probability of business-ownership in the population is just 2.2 percentage points.

To interpret these associations it is important to elucidate the correlates of PGEB, which is surely not randomly assigned to provinces. PGEB is only weakly correlated with GDP per capita. However, when we explore the provincial indices of marketization developed by Wang, Fan and Yu (2016), we find that higher PGEB provinces consistently show lower marketization scores. More specifically, in these provinces the relative share of the private sector in the economy is smaller, private businesses have a smaller share of loans, the provincial government is more interventionist and has weaker rule of law. This being said, among these measures, PGEB is the best province-level predictor for the probability that cadre parents have business-owner children. This suggests that public budgetary allocations that potentially lead to higher government-to-business flows have the strongest impact on the selection of people that go into business.

Individual characteristics and their transmission across generations can also have bearing on the interpretation of our findings. For instance, having cadre parents may capture other parental transmissible characteristics such as human capital, skills or attitudes which are useful to the conduct of business. ${ }^{4}$ We explore the role of formal human capital in the form of college education and

${ }^{4}$ Indeed, the literature on entrepreneurship mentioned above has tried to elucidate these channels to explain the observed 
find that having a college-educated parent interacted with PGEB does not weaken our coefficient of interest. To further probe this hypothesis, we explore an alternative dataset, the China Family Panel Studies (CFPS), which also tracks the profession of the parents of the respondent and which includes other individual characteristics such as risk attitudes and social skills. We show that none of these characteristics, which could potentially be transmitted within the family, can explain the cross-province pattern. ${ }^{5}$

As a complementary exercise, we show that our findings also hold when we exploit the Fiscal Stimulus in 2008 for arguably exogenous variation in PGEB. More specifically, we show that in provinces with traditionally high PGEB, the large increase in PGEB brought about by the Stimulus is associated with an increase in the propensity of business ownership among descendants of cadres. In contrast, the same proportional increase in PGEB has no such effect in provinces where PGEB had been traditionally lower.

By and large, there are three broad interpretations of this striking cross-province pattern in the likelihood of business-ownership among cadre children. First, recall that provinces with high PGEB are provinces where the private sector is lagging behind. Hence, it is possible that catching up in the development of the private sector has been a goal of these provincial government. This policy emphasis could spur children of cadres to engage in private business. ${ }^{6}$ We collect data on provincial reports and we show that private business development is less mentioned in provinces with high PGEB, which suggests this explanation cannot account for the pattern. Second, the intergenerational transmission hypothesis suggests that what we find is a consequence of the transmission of talent, aptitude or attitudes within a family. In China, talented individuals traditionally went to the government and now that the country has transited to a market economy, their children became business owners due to inherited or cultivated talent. This explanation can account for the link between cadre parents and business-owner children, but we can not find evidence that it explains the cross-province pattern. As detailed above, neither college education, nor risk attitudes display the correlations that could generate a higher likelihood of cadre children's business ownership in higher PGEB provinces. ${ }^{7}$ Finally, our findings could be generated by political connections. More specifically, there are advantages for politically connected children (e.g., better information on

\footnotetext{
intergenerational transmission of entrepreneurship.

${ }^{5}$ We find that a risk-loving attitude is correlated with being a business-owner, which aligns with existing literature (e.g. Levine and Rubinstein 2017). However, there is no strong correlation between having a cadre parent and one's own risk attitude, and the interaction of risk attitude with PGEB has no explanatory power on becoming a business-owner. ${ }^{6}$ We thank a referee for bringing up this possibility.

${ }^{7}$ While these are the most plausible candidates, we obviously cannot reject the existence of other unobservable omitted variables.
} 
business opportunities, easier access to capital, personal networks within government institutions) which are inputs to the successful running of business and whose importance increases with the role of the government in the business environment. We show two ancillary results that are consistent with this explanation. First, using opinion survey questions on the key determinants in career success, we find that business owners are more likely to identify connections with political power as the key determinant of success in business; and this identification is significantly stronger in provinces with higher PGEB. Therefore business practitioners are cognizant of the importance of connections, and more so wherever government looms larger. Second, the gap in reported income between business owners who are cadre children and those who are not is significantly increasing in PGEB. This is consistent with the idea that businesses led by cadre children are able to capture a large share of the government-to-business flows proxied by PGEB.

Limited by available survey data, our study has several important caveats. In particular, we cannot directly study business performance and sector, which means our evidence on the underlying channels is circumstantial. Ideally, one should use firm-level data to examine how personal background affects business opportunities of a firm, which has to be left for future work. Our main contribution is to document that the local economic business environment significantly shapes the influence of parental background on entrepreneurship. Overall, we demonstrate that "crony capitalism" can vary greatly across regions within a country, thus contributing to the literature on modes of capitalism which has so far focused on cross-country variation (e.g., Baumol, Litan, and Schramm 2007, Zingales 2012). Our interpretation is related to an extant literature that emphasizes the importance of personal links to power in the conduct of business (e.g., Fisman 2001, Khwaja and Mian 2005, Faccio 2006 among many others). We are the first to note that these links can systematically influence the characteristics of the entire set of business owners and therefore that these effects are not limited to very large enterprises. Our findings imply that the role of personal links hinges on the role of government in the economy, which has been less studied by the existing literature.

The paper is organized as follows. Section 2 describes the background and the data. Section 3 presents the main empirical patterns. Section 4 discusses suggestive evidence on how to interpret our findings, and Section 5 concludes. 


\section{Background and Data}

We combine individual-level surveys with provincial-level data in our analysis. We first describe the individual-level data. We then explain government business-related expenditure and the drivers of its variation.

\subsection{Individual-level Data: Parental Background and Entrepreneurship}

We obtain our individual-level data from the Chinese General Social Survey from 2006 to 2013 (CGSS), a Chinese version of the General Social Survey in the U.S. conducted by the National Opinion Research Center. The CGSS is also a part of the International Social Survey Program (ISSP) that covers 48 countries. The CGSS is a repeated cross-sectional survey, jointly conducted by the Renmin University of China and the Hong Kong Science and Technology University. Our sample includes five waves of the survey conducted in 2006, 2008, 2010, 2012, and most recently in 2013, which collects information in the year before the survey (i.e., 2005, 2007...,2012). ${ }^{8}$ A typical wave of the CGSS includes about 10,000 urban and rural households. Since owning an incorporated business is rare for the rural population, we focus on 22,801 urban residents aged between 25 and 80 . Our sample covers all the 31 provinces in mainland China and provides a province-level panel dataset.

The CGSS uses multi-stage stratified sampling design, with counties as primary sampling units. The survey adjusts its sampling frames according to existing population census. ${ }^{9}$ To examine the representativeness of the survey, we compare the characteristics in the survey with those in the census. As shown in Appendix Table A, the demographic characteristics are comparable between the survey and the census 2010. Because 2010 census does not provide occupation, we turn to the quasi-census 2005 for comparison.

Business Owners. In order to classify respondents into entrepreneurship status we use two categories. The first is business owner, which comprises all owners of incorporated businesses, who must pay corporation tax and follow corporation law. The second is self-employed, which includes owners of non-incorporated small businesses. ${ }^{10}$ The existing literature often uses an

${ }^{8}$ We cannot use earlier waves because they did not ask about entrepreneur status or parental background.

9The CGSS 2006 uses China's fifth census of 2000 as sampling frame; the CGSS 2008 uses the 1\% national population survey data in 2005 ("2005 quasi-census") as sampling frame; and the last three waves use China's sixth census of 2010 as sampling frame.

${ }^{10}$ Only $17 \%$ of this category hire any other worker, and none of them hire more than 8 people. 
encompassing category of self-employment as a proxy for entrepreneurship, but recent contributions have shown this can be problematic as it mixes necessity or subsistence entrepreneurship with opportunity or transformational entrepreneurship. On average, business-owners account for $2.2 \%$ of our respondents, and the share is higher among those with cadre parents (defined next), as shown in Table 1 for summary statics. In contrast, $11 \%$ of respondents are self-employed individuals, and the share is lower among those with cadre parents. We use the term "entrepreneur" to refer to both categories when needed in the analysis (that is, "entrepreneurs" are those who are either self-employed or business owners).

Parental Background. We focus on two types of parental background. The first one captures whether at least one parent works in government or in a public organization affiliated with the government (known as "shi ye dan wei" in Chinese, meaning public institutions). We call it a cadre parent for brevity. Public institutions are essential branches of the Chinese government, endowed with great power and influence. For example, the two major institutions that supervise and regulate the whole financial sector, the China Banking \& Insurance Regulatory Commission and the China Securities Regulatory Commission are not officially a part of the government, but are public institutions. The parents' employer is defined as their employer at the time when the respondent was 14 years old (except for the 2005 data in which it is when the respondent was 18 years old). As reported in Table 1, 19\% of urban households belong to the cadre parent group. We use all cadres as one group in our main analysis and differ the ranks of the cadre positions in additional analysis.

It is reasonable to assume that having cadre parents or not changes little over time. Job mobility between governments and private sectors is fairly low among older generations, as Chinese government is a fairly closed system. In our data, most cadre parents started to work for the government long before their children reached working age or even before their children were born. For example, among government workers who had an adult child in 2005, 83\% had their whole career in government and $12 \%$ started in state-owned enterprises.

The second important parental background is entrepreneurship. While the 2009-2012 waves of the CGSS distinguishes parents' profession between business-owners and self-employed, these two categories are lumped into a single category in the 2005 and 2007 waves. In order to preserve sample size, the analysis in the paper uses the term "entrepreneur parents" which uses this category for the 2005 and 2007 waves and merges business-owners and self-employed parents for the 20092012 waves. Because China did not begin transitioning towards market economy until the late 
1970s, it is rare for parents of older respondents to have been business owners when they were 14 . Thus, besides constraints imposed by the data, there is a good reason to merge these two categories.

Individual Characteristics. The CGSS also contains additional information on gender, age, marital status, educational attainment and minority classification of the respondents, which we use in the analysis.

\subsection{Provincial Variation in Government Intervention}

Government expenditure over GDP has been shown to be useful in capturing the influence of the government on economic activities (e.g., Alesina et al. 2002). To this end, we obtain data on provincial fiscal expenditure from 2005 to 2012 from the statistical yearbooks. ${ }^{11}$ To zoom into potential flows from government to private business, as opposed to expenditure on public services and insurance programs, we focus on expenditure in two categories: infrastructure, and manufacturing, commerce, and finance (MCF). ${ }^{12}$ Even though the level of disaggregation reported in the statistical yearbooks varies by year, we can always aggregate up to these two categories. To make this total comparable across provinces, we divide government business expenditure at the province level by provincial GDP. We refer to this measure as Provincial Government Expenditure on Business-related activities, henceforth PGEB. We describe the details in Appendix Table B.1. On average, PGEB accounts for $16 \%$ of provincial total fiscal expenditure and amounts to about $3 \%$ of provincial GDP.

Two additional facts support the relevance of this proxy as a measure of the role of government on the private business environment. First, in Appendix Table B.2 we show that PGEB is strongly correlated with private firms' receipt of government subsidies. More specifically, using data from the second National Economic Census (NEC) in 2008, we show that a one standard deviation increase in PGEB (0.02) is associated with a 0.6 percentage point increased probability of subsidy receipt, a very large effect compared to the mean probability (1.3 percentage points). This relationship is also true at the intensive margin and is robust to introducing firm-level controls.

The second fact pertains to the large fiscal economic stimulus plan that the Chinese central government approved in November of 2008 to combat the effects of the great recession and which

\footnotetext{
${ }^{11}$ Expenditure is a better measure than revenues since the majority of tax revenues is collected by the central government, but the majority of fiscal expenditure remains in lower level governments.

${ }^{12}$ Because infrastructure creates many business opportunities, we include infrastructure spending in our baseline measure. We also report the results after excluding infrastructure and focus on the narrower MCF definition.
} 
was explicitly designed to increase business activity. Of the 4 trillion RMB stimulus package, $25 \%$ was devoted to reconstruction work in the regions destroyed by the Sichuan earthquake in 2008. However, a full $75 \%$ of the remainder went to PGEB. ${ }^{13}$ As a result, PGEB went from about 2.4 percent (of provincial GDP) prior to the stimulus package to 4.8 percent post the stimulus package, while the increase in other fiscal expenditure was modest and proportionally insignificant (see the density distribution in Appendix Figure B.3). 70\% of the provincial fiscal expansion between 2008 and 2010 is in this category of expenditure.

PGEB and Marketization Index. Wang, Fan and Yu (2016) construct a set of province-year indices which are meant to capture the quality of the private business environment. These indices purport to capture different avenues of government intervention in the economy, which we expect to be correlated with PBEG. There are five components to the overall marketization index: (1) "government-market relationship" measures government size and general regulations; (2) "private economy development" measures the share of non-state-owned economy in manufacturing, fixed asset investment, and employment; (3) "product market development" measures price regulation and local protectionism; (4) "factor market development" measures credit allocation, FDI, and labor mobility; and (5) "intermediary service and law development" measures rule of law, intellectual property rights, and consumer protection. For each measure, a higher index indicates a better performance.

We present the correlations of PGEB with the overall index and its components in Table 2. There are several noteworthy features to this correlational table. First, PGEB is negatively correlated with all dimensions of the private business environment including the overall Marketization index. Hence, provinces where the government has higher PGEB correspond to provinces where the private business environment is more restrictive. Second, the negative correlation with "private economy development" shows that the private sector is relatively small in provinces with high PGEB, possibly as a result of the restrictive environment. ${ }^{14}$ Finally, "factor market development" includes the private share in total bank loans, and therefore captures financial access for the private sector, relative to the public sector. The correlation with PGEB is also negative but it is the weakest among the subindices. This makes sense, since governments can foster private access to credit without a large direct budgetary investment.

\footnotetext{
${ }^{13}$ For the breakdown of the stimulus package, announced by the National Development and Reform Commission, see: http://www.eeo.com.cn/ens/finance_investment/2009/03/07/131626.shtml.

${ }^{14}$ According to the documentation, this indicator combines three variables: private firms' share in the total revenue of manufacturing; private share in the total fixed-asset investment; private share in urban employment.
} 
In short, the negative correlations demonstrate that more PGEB is associated with a less free market economy. In the analysis below we will examine which of these provincial variables can better explain business-ownership and its intergenerational determinants.

Explaining the Variation in PGEB. The data suggests that PGEB mainly captures long-term differences across provinces in the economic role of the government. This reflects the differences already highlighted by Huang (2008), who contends that from the beginning of the reform era, some provincial governments have embraced bottom-up capitalist expansion while others have chosen a more state-driven approach. Two pieces of evidence support this interpretation. First, in our study period - 2005 to 2012- the variation in PGEB is primarily driven by differences across provinces, as opposed to differences over time. Specifically, provincial fixed effects account for $72 \%$ of the variation. Second, we find that 55\% of the cross-provincial variation in PGEB in 2007 is explained by the share of State Owned Enterprises (SOEs) in manufacturing in 1985 (presented in Appendix Figure B.4), which reflects the long term determinants of the different developmental strategies.

Crucially, it is worth noting that the cross-province variation in PGEB is only weakly associated to relative economic development. As shown in Appendix Figure B.4, while the correlation between PGEB and GDP per capita is negative, the latter only explains $22 \%$ of the variation of the former. Both poor provinces, such as Yunnan, and rich provinces, such as Shanghai, pursue a statist developmental route that is reflected in high PGEB.

\subsection{Descriptive Patterns}

We now present three descriptive patterns using data aggregated at the province level. We demean PGEB by its sample mean so that a positive value means expenditure more than average. First, as shown in panel (a) of Figure 1, there is a negative correlation between PGEB and the share of respondents who are business owners. Thus, higher PGEB does not imply a better business environment. If anything, as noted in Table 2, it indicates more government intervention that hinders entrepreneurship.

Second, panel (b) shows that the difference between the probability that a cadre descendant is a business owner and the probability that a non-cadre descedant is a business owner is larger in provinces with higher PGEB. A one standard deviation increase in PGEB (0.02) increases the difference by about 0.75 percentage points or $35 \%$ of the mean. In other words, cadre children are more likely to become business owners relative to others in provinces with higher PGEB. The pattern remains similar if we exclude children of entrepreneurs in the non-cadre group, as in 
Appendix Figure C.1.

Third, panel (c) shows that the opposite is true for descendants of entrepreneurs. In provinces where PGEB is low, children of entrepreneurs have a high likelihood of owning a business, but this advantage disappears in provinces with high government involvement. The pattern remains the same when we exclude children of cadres in the non-entrepreneur group, as in Appendix Figure C.1.

Thus, we observe that business ownership displays systematic patterns which intermingle parental background and business environment at the province level. We probe the robustness of these province-level patterns with individual-level information in the next section.

\section{Empirical Results}

We first explore the relationship between parental background, self-employment and business ownership, followed by an analysis of the effect of the local economic context on these relationships.

\subsection{Parental Background and Doing Business}

We examine the difference in the probability of being in different occupations between those with entrepreneur parents, cadre parents and others. We consider four occupations: being a business owner/self-employed/a government worker/an employee in a firm, and employ both OLS and multinomial logistic methods to reveal the links across generations.

The specification is as follows:

$$
Y_{i}=\alpha_{1} \text { CadreParent }_{i}+\alpha_{2} \text { EntrepParent }_{i}+\mathbf{X}_{i}+\text { Prov }_{p} \times \text { Year }_{t}+\varepsilon_{i, p, t},
$$

where $Y_{i}$ is a dummy indicating the respondent's occupation in our OLS estimations, with all the

other occupations grouped together in the reference group; in contrast, $Y_{i}$ is $\ln \frac{\operatorname{Pr}\left(y=j \mid \text { parent }, \mathbf{X}_{i}\right)}{\operatorname{Pr}\left(y=\text { FirmEmployee } \mid \text { parent }, \mathbf{X}_{i}\right)}$ in our multinomial logistic estimations, where $j$ can be a business owner/ self-employed/ government worker, and we leave firm employee status as the reference group.

$\mathbf{X}_{i}$ is a set of individual-level variables: gender, age, marital status, college education or not, and minority status. We include province-by-year fixed effects so that we compare individuals within a province-year cell.

We report the OLS estimates in Table 3A. Intergenerational links within sector are clear: children with cadre parents are about $60 \%$ more likely to work for the government, and children of entrepreneurs also have a higher likelihood of becoming business owners or self-employed. 
In addition, these coefficients feature some cross-sector influence of cadre parents: respondents with cadre parents also appear to be more likely to own a business in columns (3) and (4), although the coefficient is not significant in the latter. Note that the fact that cadre children are so overwhelmingly predisposed to become government workers (as noted in the coefficients in columns (1)-(2)) confounds the estimates for the rest of the columns due to the multiple choice nature of occupational choice.

To account for the nature of this choice, we report the relative risk ratios from multinomial logistic estimations in Table 3B. Results are now clear-cut. For those with cadre parents relative to those with non-cadre parents: (1) the relative risk for working in the government relative to being a firm employee increases by a factor of 2, ceteris paribus the other variables in the model; and (2) the relative risk for being a business owner relative to being a firm employee increases by a factor of 1.4. In fact, these odds of cadre children owning a business, while lower, are not statistically different from those of children of entrepreneurs. Note that cadre children do not differ systematically from the general population in the likelihood of being self-employed.

In contrast, for those with entrepreneur parents, the relative risk of being a business owner and being self-employed is 1.8-1.6 times higher than those without entrepreneur parents, while the relative risk of working in the government is not significantly different. The magnitude of 1.6 is comparable to those found in the existing literature in other countries. ${ }^{15}$ We are not aware of similar studies examining the intergenerational link across sectors (i.e., the cadre parents-business children link) and our estimate provides a benchmark for future studies.

One potential confounder for the relationship between cadre parents and businessman status could be educational attainment, which is correlated with both. Note, however, that in columns (2) and (3) of Table 3B we control for individual characteristics which include college education. Hence these intergenerational transmission links are not driven by formal education.

In sum, in modern China, both entrepreneur and cadre parental backgrounds are associated with respondents' higher likelihood of owning businesses. Once we take into account that those with cadre parents have, on average, a higher probability of working in the government, both parental backgrounds have a similar influence in the odds of business-ownership.

${ }^{15}$ See e.g. Sørensen (2007) and Lindquist et al (2015). 


\subsection{Parental Background and Local Economic Context}

Our focus now turns to investigating whether the local context determines the influence of parental background on entrepreneurship. More specifically, we ask whether the association between parental occupation and business ownership varies with the level of government intervention in the business environment. To facilitate interpretation of the interaction effect, we employ a linear specification as follows:

$$
\begin{aligned}
\text { BusinessOwner }_{i, p, t} & =\beta_{1} \text { CadreParent }_{i}+\beta_{2} \text { CadreParent }_{i} \times \text { PGEB } \\
& +\beta_{3, t} \text { EntrepParent }_{i}+\beta_{4} \text { EntrepParent }_{i} \times P G E B_{p, t} \\
& +\mathbf{X}_{i}+\mathbf{X}_{i} \times P G E B_{p, t}+\text { Prov }_{p} \times \text { Year }_{t}+\varepsilon_{i, p, t},
\end{aligned}
$$

where the definitions are the same as before and $P G E B_{p, t}$ refers to provincial government expenditure related to private business over GDP. We demean PGEB by its sample mean and divide by the standard deviation so the interaction coefficient can be interpreted as the increase in propensity of business-ownership associated with increasing PGEB by one standard deviation at the mean value of PGEB.

The interaction between parental background and PGEB on the probability of owning a business is not only statistically but economically significant. Columns (1)-(3) of Table 4 presents the estimates controlling for province-year fixed effects, individual characteristics, as well as the interaction of individual characteristics and PGEB. As noted, the coefficient in column (3) implies that an increase of PGEB by a standard deviation is associated with 0.5 percentage points increase in the odds that cadre children own a business. This is a large effect considering the average share of business owner is 2.2 percentage points. Note that this association is at the cost of those having entrepreneur parents: an increase of PGEB by a standard deviation is associated with a reduction in the business-ownership likelihood of the children of entrepreneurs of 0.75 percentage points. Therefore, two standard deviations increase in government intervention are enough to wipe out the main effect of having an entrepreneur parent.

This result demonstrates that the advantage of cadre children in provinces with more government intervention comes at the cost of other groups. The fact that children of entrepreneurs are less likely to own business in provinces with higher PGEB implies a crowding-out effect. This finding suggests that in these provinces, the skills/assets needed to create a business have more to do with the ability to manage the government-dominated business environment than with the entrepreneurial ability that children are likely to inherit from their parents.

In Table 5 we compare the association of PGEB with the measures of marketization we 
discussed in Section 2.2. In odd columns we report the coefficients for one standardized deviation increase in the marketization index as well as its components, interacted with cadre parents. In the even columns we run them together with PGEB. Two patterns emerge from these results. First, the marketization measures deliver a message similar to that using PGEB: more marketization (i.e., less government intervention) is associated with a lower propensity of business ownership among cadre children. Second, the even columns show that PGEB is a more robust predictor of the variation of this propensity across provinces than any of these other measures. Therefore, the relative size of budgetary items that are linked to transfers and transactions with the private sector seems to most precisely capture the aspects of the business environment which influence the decision of cadre children to become business owners.

There are two important sets of possible confounders that complicate interpreting the main finding in Table 4. The first is that having cadre parents may capture other parental characteristics such as more human capital to do business. To address this concern, note that in column (3) we control for the interaction of personal characteristics and PGEB. This implies that the crossprovince patterns are not driven by other individual characteristics such as education attainment. If anything, these controls make our estimate more precise. We discuss the human capital hypothesis more explicitly as a possible interpretation of this finding in Section 4.

A second concern is that PGEB may be correlated with other provincial characteristics which may drive the differences across provinces. If these omitted provincial characteristics are dimensions of government intervention, it would be consistent with our view, as shown in Table 5. However, it would be a concern for our interpretation if PGEB is correlated with provincial characteristics not directly related to government intervention in the business environment, such as economic development or public goods provision. We conduct two checks regarding this concern. First, as placebo tests, we replace PGEB in equation (2) with GDP per capita and public expenditure (on healthcare, education and social welfare). If PGEB merely reflects development levels or public goods provision, we would obtain a similar pattern with respect to these two measures. However, as shown in columns (4)-(5) of Table 4, we find no similar pattern for either measure. Column (6) shows that our main finding gets even stronger if we control for GDP per capita, public expenditure and their interactions with parental background. ${ }^{16}$

\footnotetext{
${ }^{16}$ In a similar exercise, we can control for the number of prosecutions of cadres for "corruption and bribery" and "abuse and dereliction of duty" reported in the provincial yearbooks. Adding the interaction of this measure with cadre parent does not affect our coefficient of interest. Again, like the results above, this result is not to claim that PGEB is the only measure that matters. Instead, it further suggests that compared with other measures, PGEB more precisely captures the aspects of the business environment that drive selection into business-ownership.
} 
In addition, as a complementary design, we employ the Fiscal Stimulus Package in 2008 as an exogenous shock to PGEB. As discussed above, the stimulus plan doubled PGEB in an unexpected manner. We find that the propensity of cadre children to become business owners in provinces with higher pre-stimulus PGEB gets even stronger after the stimulus, while there is no effect in laissez-faire provinces. Moreover, this association in high PGEB provinces is particularly strong for young respondents, which suggests these businesses were started during or after the stimulus plan came online. This analysis, presented in Appendix Section C.2, shows that provinces with different traditions of intervention yield different reactions to the same exogenous shock. In provinces with a statist tradition, cadre children are more likely to start businesses when PGEB swells, while in high marketization provinces the association is not present. This exercise provides time-varying evidence that is consistent with the cross-province evidence we emphasize in the main text.

As a final exercise, note that when replacing owning a business by being self-employed, we do not find a similar pattern (column (7) of Table 4). The association of PGEB and the cadre children likelihood of a business career is therefore limited to incorporated businesses. Again, this finding confirms the importance of treating business ownership and self-employment as distinct categories, as emphasized by a recent literature.

Additional Checks. We conduct several measurement checks. First, recall that we categorize those working in the government and public institutions as "cadre parents". Naturally, there exists heterogeneity among cadres - highly-ranked officials are more powerful than government workers with no rank. When separating cadre parents by their official ranks (only available in the surveys during 2009-2012), we do not have enough power to obtain results for each group. Nevertheless, we find the impact of CadreParent ${ }_{i} \times P G E B_{p, t}$ increases with rank (reported in Appendix Table C.3). ${ }^{17}$

Second, recall that we include infrastructure expenditure as part of PGEB because infrastructure projects provide many business opportunities. Our results hold if we exclude infrastructure expenditure from PGEB and focus on the narrower MCF definition. Results are reported in Appendix Table C.4.

Third, our finding is robust to excluding migrants, allaying concerns that selective migration might be behind our findings. It is also robust to using data during 2009-2012, where the PGEB categories remain exactly the same and we can control for county fixed effects. See Appendix Table

${ }^{17}$ The survey does not cover precisely the institution or department in which the respondent or the parents work, which limits our ability to exploit variation across positions. 
C. 5 for these additional results.

Alternative Data and Individual Attitudes. Finally, we explore an alternative source of data, the China Family Panel Studies (CFPS), which in recent waves also record the profession of the parents of respondents. Unfortunately the CFPS does not distinguish between business owners and self-employed and hence comparison with the CGSS requires keeping this difference in mind. To make the comparison with CGSS, we normalize the dependent variables by their means. In Appendix Table C.6 we present the following results. First, in columns (1)-(4) of Table C.6 we show that the cross-province pattern of association between the likelihood of entrepreneurship of cadres and PGEB is also present in CFPS and the magnitude is comparable to that from CGSS (around 20-25\% of the mean). This result also suggests our main findings are very unlikely to be the result of improper sampling patterns of the CGSS.

One advantage of the CPFS is that it contains data on other personal characteristics of respondents, such as risk attitudes and social skills. In columns (5)-(6) of Table C.6 we show that while a risk-loving attitude is associated with entrepreneurship, it displays no interaction with PGEB. In columns (7) and (8) we show that there is no association between the measure of social skills and entrepreneurship. Thus, although these individual characteristics can be correlated with entrepreneurship, it is difficult for them to explain the cross-province patterns in our main results.

\section{Interpretation}

We have documented a robust association between PGEB and the cross-province likelihood that cadre children become business-owners. What are the possible interpretations of this finding? Motivated by the Chinese context, we consider three broad interpretations that have different implications on the economy. In particular, we want to explore whether the business propensity of cadre children in bigger governments reflects different policy priorities of provincial governments, differences in human capital or differences in specific links with government that are useful for the conduct of business.

The Policy Priority Hypothesis. The correlations between PGEB and measures of private sector development in Table 2 suggest that the private sector is lagging behind in provinces with high PGEB. It is therefore possible that such provinces are trying to catch up and therefore have high policy priority in private sector development. If such policy push compels cadre families to focus 
their efforts onto business careers, the policy priorities of provincial government could explain the cross province pattern we uncover. Regression (6) in Table 5 above casts doubt on this explanation, since one would expect the effect of the level of private sector development to have independent explanatory power on the business-ownership of cadre children. Nonetheless, this is an important alternative hypothesis that it is worth examining directly. To do so, we collected further text data on annual government reports for the years 2005-2012, where policy priorities are explicitly spelled out. Appendix Figure C.7 demonstrates that PGEB is negatively correlated with the frequency of private economy mentions (relative to state economy mentions) in provincial government reports. This is very interesting as it dispels the notion that these provinces are trying to catch up in private sector development.

The Human Capital Hypothesis. One of the hypothesis in the literature on entrepreneurship is that the transmission of formal (i.e. education) and informal (i.e. attitudes) human capital within the family may explain the intergenerational persistence of entrepreneurship. ${ }^{18}$ In the case of China, this could explain the link between cadre parents and business-owner children because in the pre-reform era talented individuals would be overwhelmingly attracted by government jobs. These talented parents would transmit human capital to children, who then would become business owners. To explain the cross-province pattern, however, one would additionally need some reason why this would happen at a higher rate in provinces with high PGEB. To check whether this is the case, we replace the dependent variable in equation (2) with the educational outcomes of an individual. Indeed, we find that cadre children are more likely to have college education, which confirms the insight that talented individuals were attracted by government jobs in the planned economy. However, no evidence suggests that such a correlation varies with PGEB (column (1) of Table 6). In column (2), we further consider having college-educated parents and its interaction with PGEB. Again, we find that the impact of CadreParent P $_{i} P G E B_{p, t}$ on college education achievement is close to zero.

To further check whether human capital explains our main finding on Cadre Parent $_{i} \times$ $P G E B_{p, t}$, we include college parents and its interaction with $P G E B_{p, t}$ as additional controls. As shown in column (3), our finding on CadreParent ${ }_{i} \times P G E B_{p, t}$ still holds. Hence, the crossprovince pattern is not a consequence of cadre parents being a proxy for educational status. Thus, the assumption that cadre children differ in human capital is reasonable, and we find supporting evidence in the data. However, it appears difficult to use this assumption to account for the

${ }^{18}$ See e.g. Sørensen (2007) and Lindquist et al (2015) among others 
cross-province finding because one needs the difference in college education to be correlated with PGEB.

Of course, there may be other forms of human capital and transmissible characteristics that can play a role and we cannot fully reject their existence. However, recall that in Table C.6 we find that other characteristics and attitudes that may be transmissible within the family, such as risk attitudes or social skills, cannot explain the cross-province pattern either.

The Political Connections Hypothesis. The final explanation points to specific advantages that have to do with the cadre status of family members. It is conceivable that direct access to cadres in the family bestows advantages for business that are unrelated to raw talent, and that such advantages are larger when the government intervenes more in the economy and is a larger source of business for private enterprises. These can be multi-faceted. For instance, cadre children may obtain better and earlier information about business opportunities generated by the government; they may access capital more easily; their bids to public tenders may be selected more often; and their business may be more likely to be subsidized. Note that these advantages may not necessarily reflect corruption. For example, because of their informal knowledge of the preferences of cadres, their bids to public tenders or requests for subsidies may be written in such a way that are objectively more attractive for the government. However, these advantages point to a fundamental inequality in business prospects that favors those with such inside knowledge and links, and such advantages would obviously be proportional to the importance of government as a souce of business for private entreprises.

An attractive feature of this hypothesis is that it can also explain the fact children of entrepreneurs have a lower propensity of becoming business owners in provinces where the government looms large in the business environment (recall Figure C.1 and Table 4). If cadre children have a specific advantage in these environments, and these environments are not particularly nurturing to private business, it makes sense that the crowded out category are those who thrive in laissez-faire environments: the descendants of private entrepreneurs.

Several pieces of evidence support this interpretation. First, recall that in Appendix Table B.2, discussed in Section 2, we show that higher PGEB is associated with a higher percentage of firms acknowledging receipt of government subsidies, as well as higher levels of subsidy. Firms seeking these subsidies need to be incorporated, and would benefit both from specific government-related knowledge useful to successfully applying for those subsidies as well as from favorable treatment of their applications due to the influence of networks that extend within government. This is consistent with the fact that (1) the patterns we uncover are only present for incorporated business owners, 
and (2) those with cadre parents are more often business owners in places where government intervention is higher.

Second, not only cadre children have a higher propensity of business-ownership in higher PGEB provinces, they also seem to be doing better. While CGSS does not report information about the business of respondents, it reports income from job, which we use as a crude proxy. This information allows to investigate the following question: Do cadre-children business owners earn more relative to other business owners in higher PGEB provinces? To investigate this question, we employ the following specifications:

$$
\begin{aligned}
\ln _{\text {Income }_{i, p, t}} & =\beta_{1} \text { CadreParent }_{i}+\beta_{2} \text { BusinessOwner }_{i}+\beta_{3} \text { CadreParent }_{i} \times \text { BusinessOwner }_{i} \\
& +\beta_{4} \text { CadreParent }_{i} \times \text { PGEB } \text { Pat, }_{p}+\beta_{5} \text { BusinessOwner }_{i} \times \text { PGE }_{p, t} \\
& +\beta_{6} \text { CadreParent }_{i} \times \text { BusinessOwner }_{i} \times \text { PGE }_{p, t}+\text { Prov }_{p} \times \text { Year }_{t}+\varepsilon_{i, p, t},
\end{aligned}
$$

In columns (1) and (2) of Table 7, we show that the income reported by business owners who have cadre parents is not different from the income reported by other business owners, on average across China. However, columns (3) and (4) yield a striking result: the gap in income between business owners who are cadre children and those who are not is very strongly increasing in PGEB. That is, in provinces with strong government role in the business environment, business owners who have cadres in the family do significantly better than those who do not. This, coupled with the fact that more cadre children become business owners in high PGEB provinces, cannot be explained by a uniformly more difficult business environment in such provinces. Instead, under the assumption that income reported by business owners proxies the degree of success of their businesses, it suggests that cadre children have an easier time setting up a successful business in these contexts. This would be naturally explained by a specific advantage of cadre children in capturing the private business generated by the government.

Third, we can provide direct evidence that PGEB is correlated with the attitude of business owners towards the government. The CGSS survey data in 2005 includes a subjective evaluation of the determinants of career success. Panel B of summary statistics in Table 1 lists the four determinants of career success covered by the survey: connections with political power, hard work, luck, and ambition. Each respondent rates each factor as: essential, very important, important, not very important, not important at all, or hard to say. For each factor, we code the answer "essential" as 1 and the rest as 0 . For example, luck is regarded by the average respondent to be a less essential determinant of success than the rest. We proceed to examine how PGEB affects business owners' perception on what determines career success. Because business owners with 
and without cadre background compete in the same business environment, we do not expect their perception on determinants of business success to differ by parental background. Thus, we focus on understanding how business owners' perception varies by PGEB, which proxies how free the business environment is.

Column (1) of Table 8 shows that on average, business owners are 9 percentage points more likely to see political connections as a key determinant in career success. When PGEB increases by one standard deviation, this effect doubles, as reported in column (2). For the other three determinants in columns (3)-(8), neither the correlation of being a business owner nor its interacted effect with PGEB are positive and significant. These results suggest that connections with the government are essential elements for the successful conduct of business, and that their relative importance strongly increases with the degree of involvement of the government in the economy. Furthermore, this seems to be well recognized by business owners.

\section{Conclusion}

While there exists an extensive literature on the determinants of entrepreneurship, few studies have paid attention to the interaction of individual characteristics and government policies. In this study, we document for the first time that those with cadre parents have higher odds of becoming business owners, compared to the general population. More importantly, we also show that the effect of parental background, cadre and entrepreneur, on children's business-ownership changes significantly with government's involvement in the economy.

We contribute to the literature on parental determinants of entrepreneurship by demonstrating that the economic context matters for intergenerational transmission. Not only government intervention weakens it, but it also fosters the influence of contacts with government, and with it the number of children of government cadres who become business owners. This suggests that the current debate on the relative importance of different channels of intergenerational transmission needs to acknowledge that the contribution of each factor is likely to be highly contingent on institutional context. We also show in a novel context that disaggregating entrepreneurship into its different components of necessity and opportunity is a useful analytical tool: the importance of cadre parents and government intervention is circumscribed to incorporated businesses and it does not affect self-employment, which mostly captures necessity entrepreneurship in the context of China.

Finally, we have shown that institutional context is important enough to shape the entire set of 
people who engage in business. We hope that further research can elucidate the welfare implications of this phenomenon. In particular, access to the performance, characteristics and sector of the business created by those who are descendants of cadres would provide more information on the selection process that yields the patterns we have uncovered.

\section{References}

[1] Alesina, Alberto, Silvia Ardagna, Roherto Perotti, and Fabio Schiantarelli (2002), "Fiscal Policy, Profits, and Investment," American Economic Review, Vol. 92: 571-589.

[2] Baumol, William J (1990), "Entrepreneurship: Productive, Unproductive, and Destructive," Journal of Political Economy, Vol. 98(5): 893-921

[3] Baumol, William J., Robert E. Litan, and Carl J. Schramm (2007), Good Capitalism, Bad Capitalism, and the Economics of Growth and Prosperity. Yale University Press.

[4] Djankov, Simeon, Yingyi Qian, Gerard Roland, and Ekaterina Zhuravskaya (2006), "Who are China's Entrepreneurs?," American Economic Review Vol. 96: 348-352.

[5] Dunn, Thomas and Douglas Holtz-Eakin (2000), "Financial Capital, Human Capital, and the Transition to SelfEmployment: Evidence from Intergenerational Links," Journal of Labor Economics, 18(2): 282-305.

[6] Faccio, Mara (2006), "Politically Connected Firms," American Economic Review Vol. 96: 369-386.

[7] Ferchen, Matthew (2012), "Informality in China and Latin America: Comparisons and Interactions," in Setting the Agenda: Asia and Latin America in the 21st Century.

[8] Fisman, Raymond (2001), "Estimating the Value of Political Connections," American Economic Review, Vol. 91: 1095-1102.

[9] Huang, Yasheng (2008), Capitalism with Chinese Characteristics: Entrepreneurship and the State. Cambridge University Press.

[10] Khwaja, Asim Ijaz and Atif Mian (2005), "Do Lenders Favor Politically Connected Firms? Rent Provision in an Emerging Financial Market," Quarterly Journal of Economics, Vol. 120: 1371-1411.

[11] Levine, Ross, and Yona Rubinstein (2017), "Smart and Illicit: Who Becomes and Entrepreneur and do they Earn More?," Quarterly Journal of Economics, Vol. 132: 963-1018

[12] Li, Hongbin, Lingsheng Meng, Qian Wang and Li-An Zhou (2008), "Political connections, Financing and Firm Performance: Evidence from Chinese Private Firms,” Journal of Development Economics, Vol. 87: 283-299.

[13]

Lindquistetal2015 Lindquist, Matthew, Joeri Sol, and Mirjam Van Praag (2015), “Why Do Entrepreneurial Parents Have Entrepreneurial Children?" Journal of Labor Economics, Vol. 33: 269-296.

[14] Lucas (1978) "On the Size Distribution of Business Firms," The Bell Journal of Economics: 508-523.

[15] Parker, Simon (2018), The Economics of Entrepreneurship. Cambridge University Press.

[16] Schoar, Antoinette (2010) “The Divide between Subsistence and Transformational Entrepreneurship," Innovation Policy and the Economy, 10(1): 57-81.

[17] Sørensen, Jesper (2007), "Closure and Exposure: Mechanisms in the Intergenerational Transmission of Selfemployment," Research in the Sociology of Organizations, 25: 83-124. 
[18] Schumpeter, Joseph A (1911) [1961] The Theory of Economic Development: An Inquiry into Profits, Capital, Credit, Interest, and the Business Cycle. New York: OUP

[19] Wang, Xiaolu, Fan Gang, and Yu Jingwen (2016), Marketization Index of Chinaâs Provinces: NERI Report 2016. Social Sciences Academic Press.

[20] Zingales, Luigi (2012), A Capitalism for the People: Recapturing the Lost Genius of American Prosperity. Basic books. 
Figure 1: Descriptive Patterns - Different Outcomes vs. PGEB

(a) Prob. Being a Business Owner

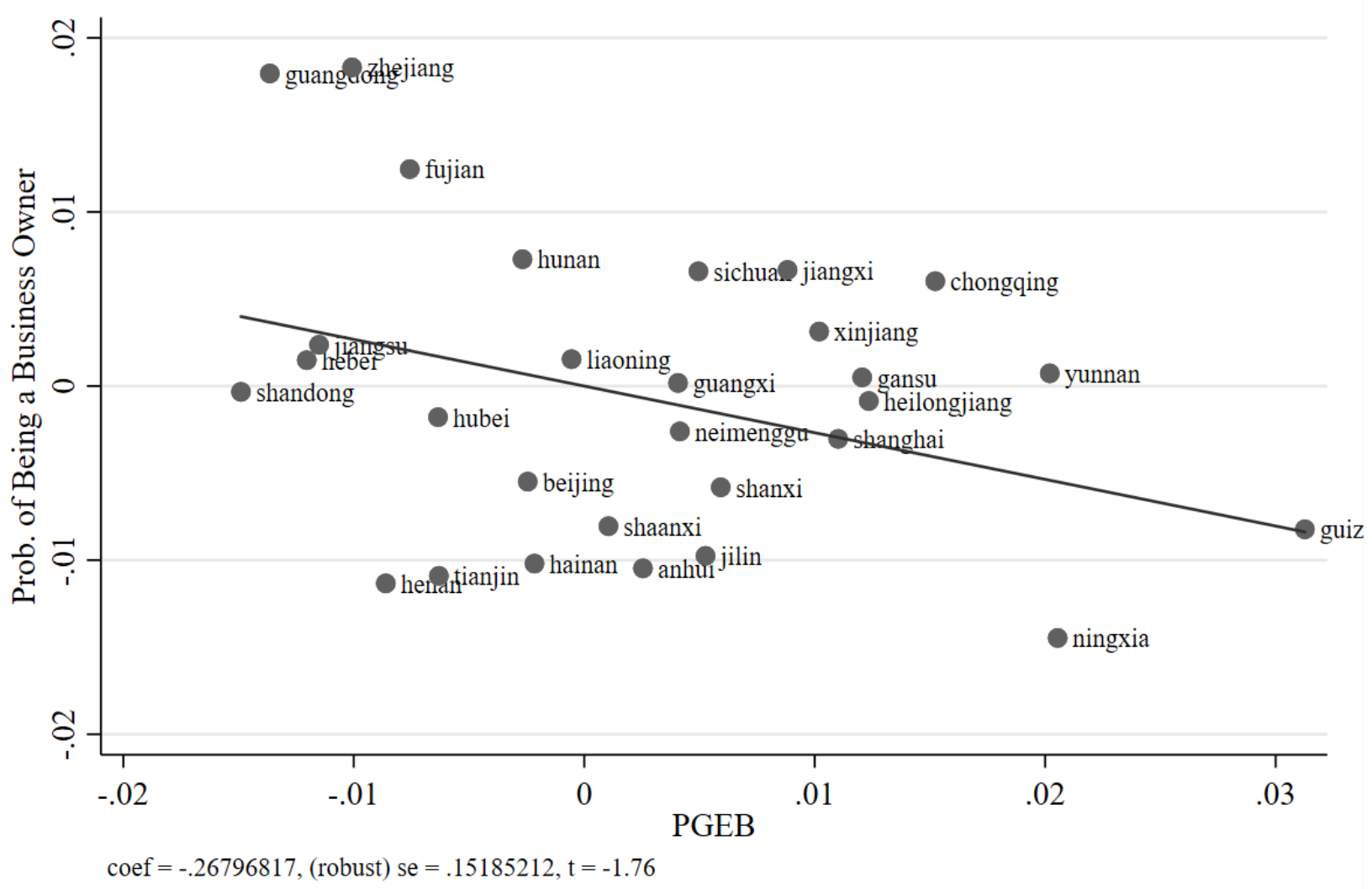

(b) Diff b/w Cadre Children and Others

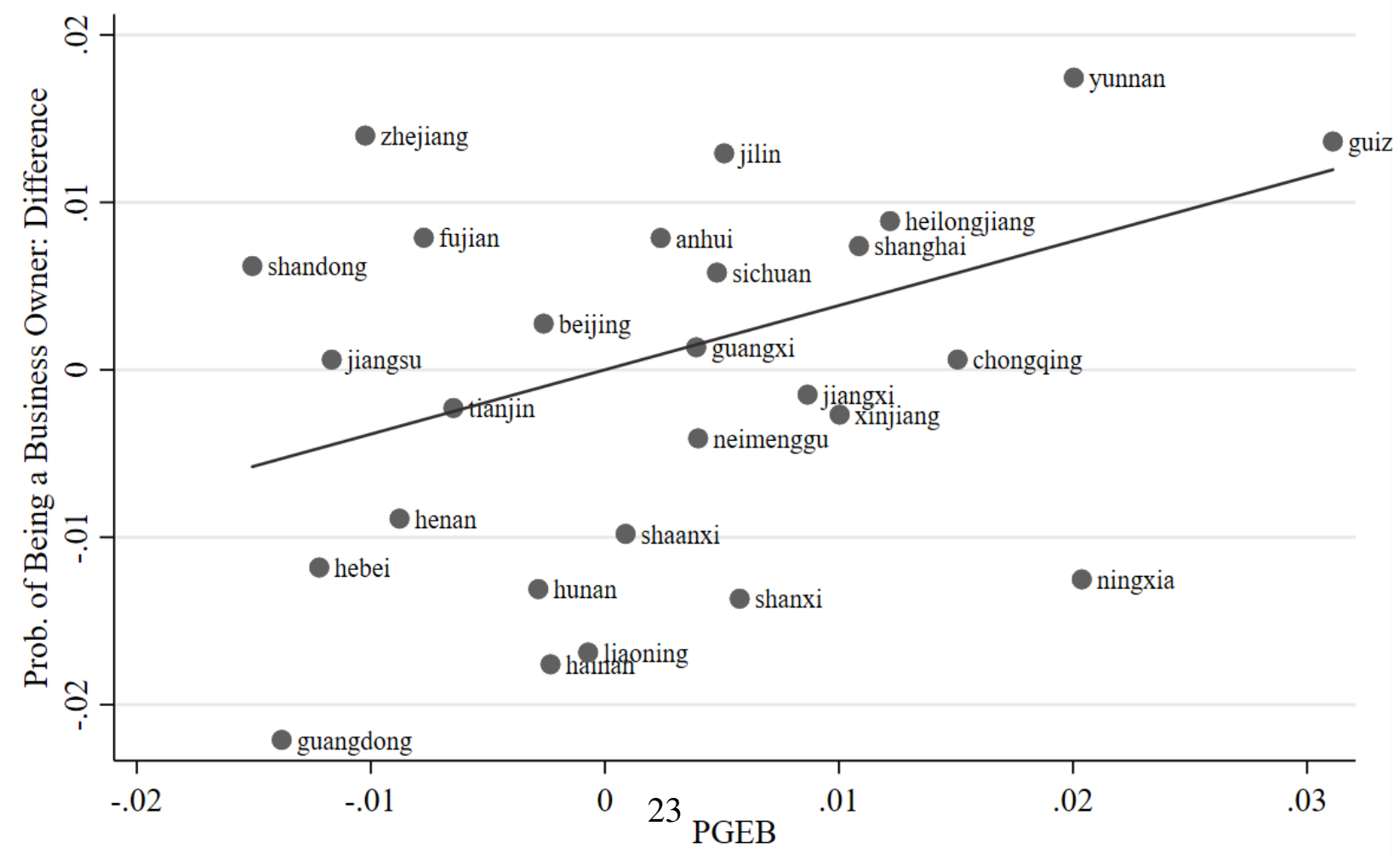

coef $=.38416326$, (robust) $\mathrm{se}=.18618219, \mathrm{t}=2.06$ 


\section{Descriptive Patterns - Different Outcomes vs. PGEB (Figure 1 continued)}

(c) Diff b/w Entrepreneur Children and Others

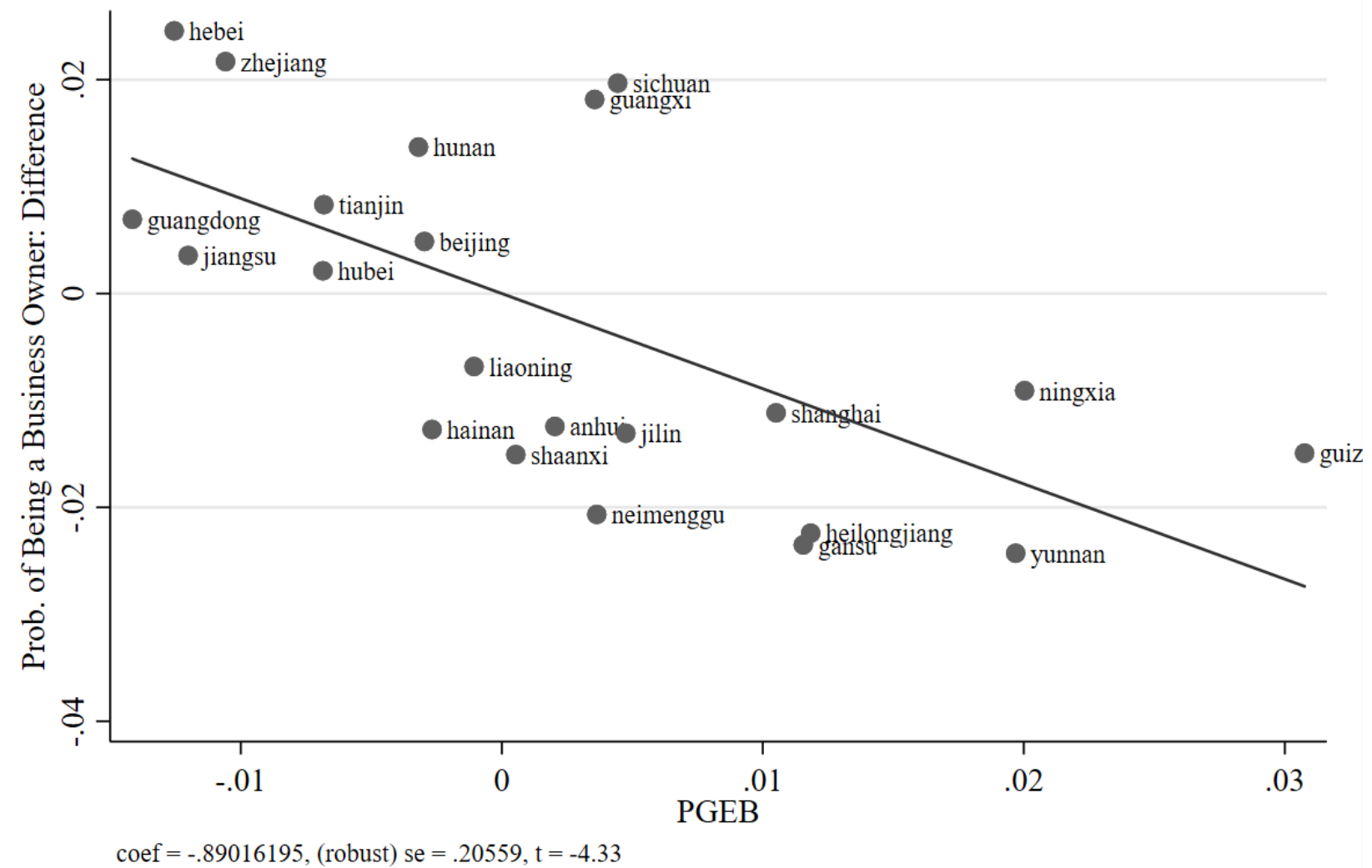

Notes: Figure (a): the share of business owners is lower in provinces with higher PGEB (provincial government expenditure on business). Figure (b): the difference between cadre children and non-cadre children increases with PGEB. Figure (c): the difference between entrepreneur children and commoner children decreases with PGEB. Outliers are excluded in these figures. 
Table 1: Summary Statistics

\begin{tabular}{lcc}
\hline & Cadre parent=1 & Cadre parent=0 \\
\hline Variable & Mean (std.) & Mean (std.)
\end{tabular}

A. CGSS 2005-2012, N=22,801

$\begin{array}{lll}\text { Entrepreneur (Business owner/Self-employed) } & 0.119(0.324) & 0.132(0.338) \\ \text { Business owner } & 0.026(0.158) & 0.021(0.143) \\ \text { Self-employed } & 0.094(0.291) & 0.111(0.314) \\ \text { College } & 0.411(0.492) & 0.224(0.417) \\ \text { College education of parents } & 0.197(0.398) & 0.028(0.164) \\ \text { Female } & 0.496(0.500) & 0.506(0.500) \\ \text { Married } & 0.904(0.294) & 0.934(0.249) \\ \text { Ethnic Minorities } & 0.074(0.262) & 0.056(0.231)\end{array}$

B. Key Determinants in Career Success, from CGSS 2005, N=4,690

$\begin{array}{lll}\text { Connection with powerful officials } & 0.226(0.418) & 0.253(0.435) \\ \text { Hard work } & 0.321(0.467) & 0.325(0.468) \\ \text { Luck } & 0.079(0.270) & 0.109(0.312) \\ \text { Ambition } & 0.341(0.474) & 0.350(0.477)\end{array}$

C. Family and Provincial Characteristics 2005-2012

Cadre parents

$0.192(0.394)$

Entrepreneur parents

$0.050(0.219)$

PGEB: Provincial government expenditure

on business-related activities over GDP

$0.029(0.020)$

Provincial government other expenditure over GDP

$0.151(0.067)$

Notes: This table presents the summary statistics for the main variables. CGSS covers households with both urban and rural Hukou. We focus on the urban ones because cadre parents and business owners are of little relevance for individuals with rural Hukou. 
Table 2: Correlations b/w PGEB and Other Measures of Institutions

\begin{tabular}{|c|c|c|c|c|c|c|c|}
\hline & PGEB & $\begin{array}{c}\text { Overall } \\
\text { marketization }\end{array}$ & $\begin{array}{l}\text { Govt-market } \\
\text { relationship }\end{array}$ & $\begin{array}{l}\text { Private } \\
\text { economy }\end{array}$ & $\begin{array}{c}\text { Product market } \\
\text { development }\end{array}$ & $\begin{array}{c}\text { Factor market } \\
\text { development }\end{array}$ & $\begin{array}{c}\text { Intermediary } \\
\text { service-law }\end{array}$ \\
\hline PGEB & 1.00 & & & & & & \\
\hline Overall marketization & -0.59 & 1.00 & & & & & \\
\hline Govt-market relationship & -0.72 & 0.85 & 1.00 & & & & \\
\hline Private economy & -0.50 & 0.87 & 0.74 & 1.00 & & & \\
\hline Product market development & -0.64 & 0.66 & 0.66 & 0.65 & 1.00 & & \\
\hline Factor market development & -0.36 & 0.81 & 0.54 & 0.59 & 0.33 & 1.00 & \\
\hline Intermediary service and law & -0.39 & 0.89 & 0.66 & 0.65 & 0.39 & 0.73 & 1.00 \\
\hline
\end{tabular}

Notes: This table shows the correlations between PGEB (Provincial Government Expenditure on Business-related activities) and other measures of institutions. The data come from province-year measures on PGEB and other measures of institutions. 
Table 3A: Parent Background and Child Occupations: OLS Estimates

\begin{tabular}{lcccccc}
\hline & $(1)$ & $(2)$ & $(3)$ & $(4)$ & $(5)$ & $(6)$ \\
\cline { 2 - 7 } Dependent variable & $\begin{array}{c}\text { Government worker } \\
(0 / 1, \text { mean } 0.217)\end{array}$ & $\begin{array}{c}\text { Business owner } \\
(0 / 1, \text { mean }\end{array}$ & $\begin{array}{c}\text { Self-employed } \\
(0 / 1, \text { mean }\end{array}$ \\
& & & & & & \\
Cadre parent & $0.144^{* * *}$ & $0.115^{* * *}$ & $0.006^{* *}$ & 0.003 & $-0.009^{*}$ & $-0.011^{* *}$ \\
Entrepreneur parent & $(0.009)$ & $(0.009)$ & $(0.003)$ & $(0.003)$ & $(0.005)$ & $(0.005)$ \\
& -0.006 & -0.006 & $0.016^{* * *}$ & $0.014^{* *}$ & $0.063^{* * *}$ & $0.057^{* * *}$ \\
& $(0.012)$ & $(0.011)$ & $(0.006)$ & $(0.006)$ & $(0.013)$ & $(0.013)$ \\
Province FE $\times$ Year FE & & & & & & \\
Individual Characteristics & $\mathrm{Y}$ & $\mathrm{Y}$ & $\mathrm{Y}$ & $\mathrm{Y}$ & $\mathrm{Y}$ & $\mathrm{Y}$ \\
Observations & 22,801 & 22,801 & 22,801 & 22,801 & 22,801 & 22,801 \\
R-squared & 0.057 & 0.139 & 0.015 & 0.022 & 0.039 & 0.067 \\
\hline
\end{tabular}

Table 3B: Relative Risk Ratios in Diff. Occupations by Parental Background - Multinomial Logit

\begin{tabular}{|c|c|c|c|}
\hline & (1) & (2) & (3) \\
\hline \multicolumn{4}{|l|}{$\begin{array}{l}\text { Reference group: being a firm employee } \\
\text { Being a government worker }\end{array}$} \\
\hline Cadre parent & $\begin{array}{c}2.327 * * * \\
(0.122)\end{array}$ & $\begin{array}{c}2.056 * * * \\
(0.120)\end{array}$ & $\begin{array}{c}2.043 * * * \\
(0.104)\end{array}$ \\
\hline Entrepreneur parent & $\begin{array}{c}1.116 \\
(0.095) \\
\end{array}$ & $\begin{array}{c}1.047 \\
(0.093) \\
\end{array}$ & $\begin{array}{c}1.047 \\
(0.092)\end{array}$ \\
\hline \multicolumn{4}{|l|}{ Being a business owner } \\
\hline Cadre parent & $\begin{array}{c}1.656 * * * \\
(0.187)\end{array}$ & $\begin{array}{c}1.406 * * * \\
(0.162)\end{array}$ & $\begin{array}{c}1.413 * * * \\
(0.167)\end{array}$ \\
\hline Entrepreneur parent & $\begin{array}{c}2.225 * * * \\
(0.379)\end{array}$ & $\begin{array}{c}1.912 * * * \\
(0.315)\end{array}$ & $\begin{array}{c}1.750 * * * \\
(0.300)\end{array}$ \\
\hline \multicolumn{4}{|l|}{ Being self-employed } \\
\hline Cadre parent & $\begin{array}{l}1.120 * \\
(0.075)\end{array}$ & $\begin{array}{l}1.058 \\
(0.070)\end{array}$ & $\begin{array}{l}1.080 \\
(0.073)\end{array}$ \\
\hline Entrepreneur parent & $\begin{array}{c}1.921^{* * *} \\
(0.186)\end{array}$ & $\begin{array}{c}1.763^{* * *} * \\
(0.169)\end{array}$ & $\begin{array}{c}1.579 * * * \\
(0.015)\end{array}$ \\
\hline Individual characteristics & & $\mathrm{Y}$ & $\mathrm{Y}$ \\
\hline Province FE* Year FE & & & $\mathrm{Y}$ \\
\hline Observations & 22,801 & 22,801 & 22,801 \\
\hline
\end{tabular}

Notes: In Table 3A, the comparison group is all other occupations. In Table 3B, the reference group is being a firm employee. Individual characteristics include: age, gender, marital status, ethnic minority status and college education. Standard errors are clustered at the province-year level. Significance level: ${ }^{*} p<0.1,{ }^{* *} p<0.05,{ }^{* * *} p<0.01$. 
Table 4: The Impact of Cadre Parent $\times$ PGEB in Determining Business Ownership

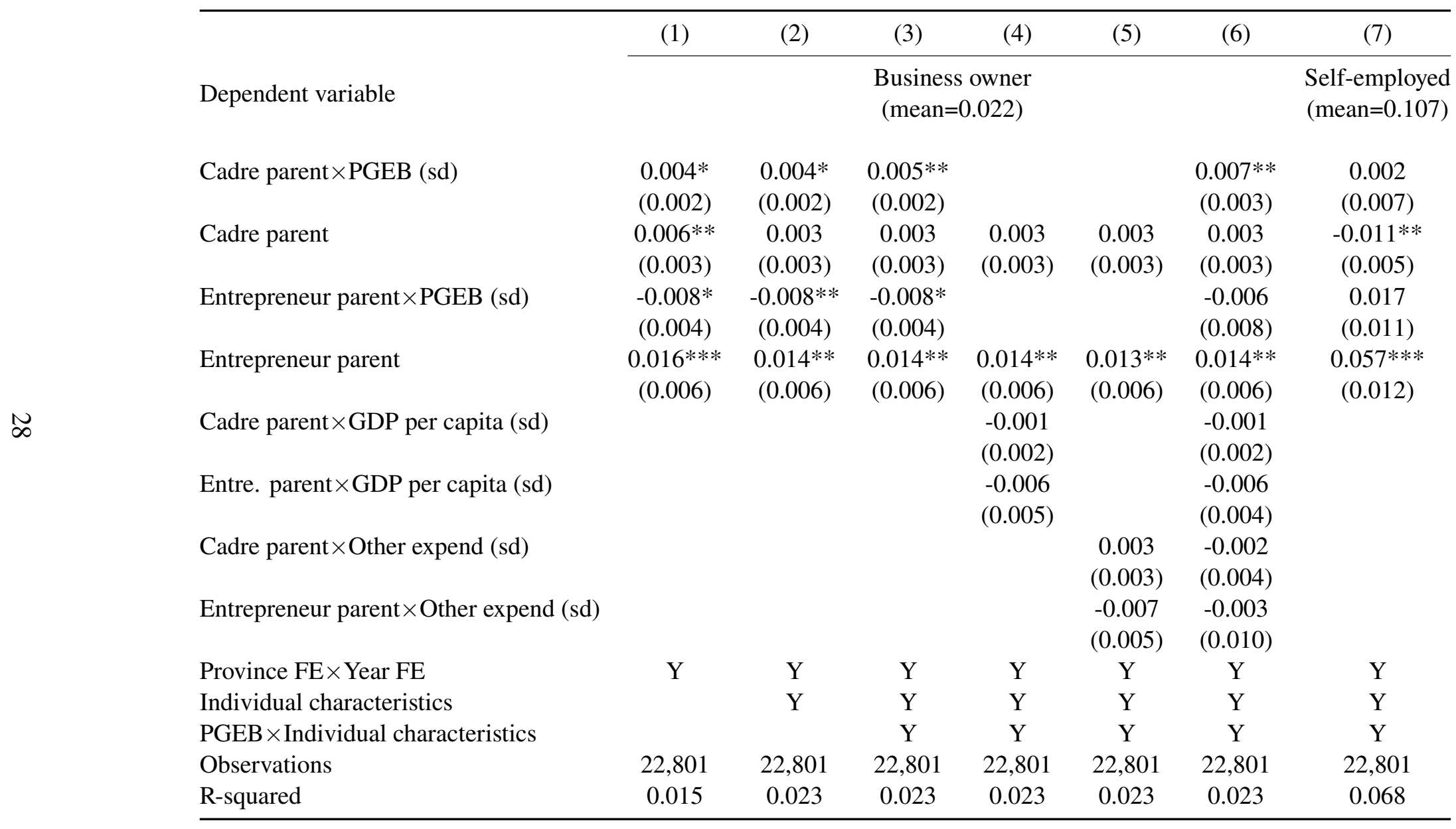

Notes: This table shows that the advantage in becoming a business owner (1) increases with PGEB for those with cadre parents and (2) decreases with PGEB for those with entrepreneur parents. Individual characteristics include: age, gender, marital status, ethnic minority status, and college education. Standard errors are clustered at the province-year level. Significance level: $* p<0.1$, $* * p<0.05$, $* * * p<0.01$. 
Table 5: PGEB vs. Other Measures of Institutions in Determining Business Ownership

Dependent variable: Business owner

\begin{tabular}{|c|c|c|c|c|c|c|c|c|c|c|c|c|}
\hline & (1) & (2) & (3) & (4) & (5) & (6) & (7) & (8) & (9) & (10) & (11) & (12) \\
\hline Cadre parent $\times$ PGEB $($ sd) & & $\begin{array}{c}0.005 * * \\
(0.002)\end{array}$ & & $\begin{array}{c}0.007 * * * \\
(0.002)\end{array}$ & & $\begin{array}{l}0.004 * \\
(0.002)\end{array}$ & & $\begin{array}{c}0.005^{* * *} \\
(0.002)\end{array}$ & & $\begin{array}{c}0.005^{* *} \\
(0.002)\end{array}$ & & $\begin{array}{c}0.005^{* *} \\
(0.002)\end{array}$ \\
\hline Cadre parent $\times$ Marketization (sd) & $\begin{array}{l}-0.004 \\
(0.003)\end{array}$ & $\begin{array}{l}-0.002 \\
(0.003)\end{array}$ & & & & & & & & & & \\
\hline Cadre parent $\times$ Gov-mkt (sd) & & & $\begin{array}{l}-0.002 \\
(0.003)\end{array}$ & $\begin{array}{c}0.002 \\
(0.003)\end{array}$ & & & & & & & & \\
\hline Cadre parent $\times$ Private economy (sd) & & & & & $\begin{array}{l}-0.005^{*} \\
(0.002)\end{array}$ & $\begin{array}{l}-0.002 \\
(0.003)\end{array}$ & & & & & & \\
\hline Cadre parent $\times$ Product market $(\mathrm{sd})$ & & & & & & & $\begin{array}{l}-0.003 \\
(0.003)\end{array}$ & $\begin{array}{l}-0.000 \\
(0.003)\end{array}$ & & & & \\
\hline Cadre parent $\times$ Factor market $(\mathrm{sd})$ & & & & & & & & & $\begin{array}{l}-0.004^{*} \\
(0.002)\end{array}$ & $\begin{array}{l}-0.003 \\
(0.002)\end{array}$ & & \\
\hline Cadre parent $\times$ Intermediary (sd) & & & & & & & & & & & $\begin{array}{l}-0.002 \\
(0.002)\end{array}$ & $\begin{array}{l}-0.001 \\
(0.002)\end{array}$ \\
\hline Cadre Parent & $\begin{array}{c}0.018 \\
(0.011)\end{array}$ & $\begin{array}{c}0.009 \\
(0.011)\end{array}$ & $\begin{array}{c}0.012 \\
(0.014)\end{array}$ & $\begin{array}{l}-0.010 \\
(0.014)\end{array}$ & $\begin{array}{l}0.016^{*} \\
(0.008)\end{array}$ & $\begin{array}{c}0.009 \\
(0.009)\end{array}$ & $\begin{array}{c}0.021 \\
(0.020)\end{array}$ & $\begin{array}{c}0.002 \\
(0.019)\end{array}$ & $\begin{array}{l}0.012^{*} \\
(0.007)\end{array}$ & $\begin{array}{c}0.010 \\
(0.006)\end{array}$ & $\begin{array}{c}0.006 \\
(0.005)\end{array}$ & $\begin{array}{c}0.003 \\
(0.005)\end{array}$ \\
\hline Province FE $\times$ Year FE & Y & Y & Y & Y & Y & $\mathrm{Y}$ & $\mathrm{Y}$ & $\mathrm{Y}$ & Y & Y & Y & Y \\
\hline Individual characteristics & Y & Y & $\mathrm{Y}$ & $\mathrm{Y}$ & Y & $\mathrm{Y}$ & $\mathrm{Y}$ & $\mathrm{Y}$ & $\mathrm{Y}$ & $\mathrm{Y}$ & $\mathrm{Y}$ & $\mathrm{Y}$ \\
\hline Individual char. $\times$ Market index & Y & Y & $\mathrm{Y}$ & Y & $\mathrm{Y}$ & Y & Y & $\mathrm{Y}$ & Y & Y & Y & Y \\
\hline Individual char $\times$ PGEB & & $\mathrm{Y}$ & & $\mathrm{Y}$ & & Y & & Y & & $\mathrm{Y}$ & & $\mathrm{Y}$ \\
\hline Observations & 22,801 & 22,801 & 22,801 & 22,801 & 22,801 & 22,801 & 22,801 & 22,801 & 22,801 & 22,801 & 22,801 & 22,801 \\
\hline R-squared & 0.022 & 0.022 & 0.022 & 0.023 & 0.022 & 0.023 & 0.022 & 0.023 & 0.022 & 0.023 & 0.022 & 0.023 \\
\hline
\end{tabular}

Notes: This table shows that PGEB provides a useful and likely more precise proxy for government intervention in the economy. Individual characteristics include: age, gender, marital status, ethnic minority status, and college education. Standard errors are clustered at the province-year level. Significance level: $* p<0.1, * * p<0.05, * * * p<0.01$. 
Table 6: The Human Capital Hypothesis

\begin{tabular}{lccc}
\hline & $(1)$ & $(2)$ & $(3)$ \\
\cline { 2 - 4 } Dependent variable & \multicolumn{2}{c}{ College } & Business owner \\
& -0.002 & 0.000 & $0.005^{*}$ \\
Cadre parent $\times$ PGEB (sd) & $(0.006)$ & $(0.006)$ & $(0.003)$ \\
Cadre Parent & $0.130^{* * *}$ & $0.092^{* * *}$ & 0.000 \\
& $(0.008)$ & $(0.008)$ & $(0.003)$ \\
Entrepreneur parent $\times$ PGEB (sd) & 0.002 & 0.001 & $-0.008^{*}$ \\
& $(0.015)$ & $(0.014)$ & $(0.004)$ \\
Entrepreneur Parent & $0.014^{* *}$ & $0.040^{* * *}$ & $0.042^{* * *}$ \\
& $(0.006)$ & $(0.014)$ & $(0.014)$ \\
College parent $\times$ PGEB (sd) & & -0.015 & 0.005 \\
& & $(0.016)$ & $(0.009)$ \\
College Parent & & $0.245^{* * *}$ & $0.017^{* * *}$ \\
& & $(0.013)$ & $(0.006)$ \\
Province FE $\times$ Year FE & Y & $\mathrm{Y}$ & $\mathrm{Y}$ \\
PGEB $\times$ Individual char.(exclud.college) & $\mathrm{Y}$ & $\mathrm{Y}$ & $\mathrm{Y}$ \\
Individual char. (exclud.college) & $\mathrm{Y}$ & $\mathrm{Y}$ & $\mathrm{Y}$ \\
College, PGEB $\times$ College & & & $\mathrm{Y}$ \\
Observations & 22,801 & 22,801 & 22,801 \\
R-squared & 0.207 & 0.222 & 0.024 \\
\hline
\end{tabular}

Notes: This table shows that it is difficult to use human capital to explain the interactive role of Cadre Parent and PGEB, because one needs the difference in human capital to differ by PGEB. The individual characteristics include age, gender, ethnic minority status, and marriage status. Standard errors are clustered at the province-year level. Significance level: ${ }^{*} p<0.1,{ }^{* *} p<0.05,{ }^{* * *} p<0.01$. 
Table 7: The Gap in Reported Income between Business Owners

Dependent variable: In Income

\begin{tabular}{lcccc}
\hline & $(1)$ & $(2)$ & $(3)$ & $(4)$ \\
\cline { 2 - 5 } & & & & \\
Cadre parent $\times$ Business owner $\times$ PGEB $(\mathrm{sd})$ & & & $0.246^{* * *}$ & $0.245^{* *}$ \\
& & & $(0.082)$ & $(0.102)$ \\
Cadre parent & $0.221^{* * *}$ & $0.109^{* * *}$ & $0.221^{* * *}$ & $0.110^{* * *}$ \\
& $(0.016)$ & $(0.014)$ & $(0.016)$ & $(0.014)$ \\
Business owner & $0.779^{* * *}$ & $0.690^{* * *}$ & $0.775^{* * *}$ & $0.686^{* * *}$ \\
& $(0.057)$ & $(0.057)$ & $(0.057)$ & $(0.056)$ \\
Business owner $\times$ Cadre parent & -0.081 & -0.049 & -0.063 & -0.032 \\
& $(0.143)$ & $(0.141)$ & $(0.138)$ & $(0.135)$ \\
Cadre parent $\times$ PGEB (sd) & & & 0.000 & 0.002 \\
& & & $(0.015)$ & $(0.012)$ \\
Business owner $\times$ PGEB (sd) & & & -0.020 & -0.022 \\
& & & $(0.033)$ & $(0.030)$ \\
Province FE $\times$ Year FE & Y & Y & Y & Y \\
Individual characteristics & & Y & & Y \\
Individual char. $\times$ Businessowner $\times$ PGEB & & & & Y \\
Observations & 14,269 & 14,269 & 14,269 & 14,269 \\
R-squared & 0.350 & 0.469 & 0.350 & 0.471 \\
\hline
\end{tabular}

Notes: This table shows that the gap in reported income between business owners who are cadre children and those who are not is significantly increasing in PGEB. The individual characteristics include age, gender, ethnic minority status, marriage status, and college education. Standard errors are clustered at the province-year level. Significance level: $* p<0.1, * * p<0.05, * * * p<0.01$. 
Table 8: Self-evaluations of the Key Determinants in Career Success

\begin{tabular}{lcccccccc}
\hline & $(1)$ & $(2)$ & $(3)$ & $(4)$ & $(5)$ & $(6)$ & $(7)$ & $(8)$ \\
\cline { 2 - 9 } Dependent variable & \multicolumn{2}{l}{ Power (mean=0.25) } & Hard work (mean=0.32) & Ambition (mean=0.35) & Luck (mean=0.10) \\
Business owner & $0.091^{* *}$ & $0.126^{* * *}$ & $0.072^{*}$ & 0.054 & 0.010 & 0.002 & -0.005 & -0.017 \\
& $(0.040)$ & $(0.034)$ & $(0.041)$ & $(0.042)$ & $(0.045)$ & $(0.039)$ & $(0.018)$ & $(0.016)$ \\
Business owner $\times$ PGEB (sd) & & $0.111^{* *}$ & & -0.060 & & -0.025 & & -0.039 \\
& & $(0.047)$ & & $(0.068)$ & & $(0.059)$ & & $(0.023)$ \\
Province FE & & & & & & & & $Y$ \\
Individual characteristics & $\mathrm{Y}$ & $\mathrm{Y}$ & $\mathrm{Y}$ & $\mathrm{Y}$ & $\mathrm{Y}$ & $\mathrm{Y}$ & $\mathrm{Y}$ & $\mathrm{Y}$ \\
Observations & 4,690 & 4,690 & 4,690 & 4,690 & 4,690 & 4,690 & 4,690 & 4,690 \\
R-squared & 0.100 & 0.101 & 0.067 & 0.067 & 0.073 & 0.073 & 0.034 & 0.035 \\
\hline
\end{tabular}

Notes: The dependent variable is a dummy variable if a respondent considers the factor listed in the first row as an "essential" determinant in career success. This table shows that business owners appreciate power more, especially in provinces with high PGEB. The individual characteristics include age, gender, ethnic minority status, marriage status, and college education. Standard errors are clustered at the province-year level. Significance level: $* p<0.1, * * p<0.05, * * *<0.01$. 


\section{Online Appendix}

\section{Table of Contents}

$\begin{array}{lll}\text { A CGSS vs. Census Data } & \text { A-2 }\end{array}$

$\begin{array}{ll}\text { B Understanding PGEB } & \text { A-2 }\end{array}$

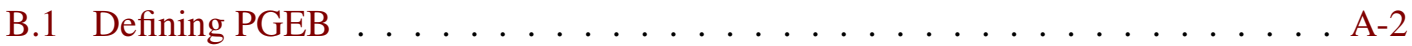

B.2 PGEB and Firm Subsidy $\ldots \ldots \ldots \ldots \ldots \ldots$ A-3 . . . . . . . . . .

B.3 PGEB pre-post the Fiscal Stimulus $2008 \ldots \ldots \ldots$. . . . . . . . . . A-4

B.4 The Variation in PGEB . . . . . . . . . . . . . . . . A-6

$\begin{array}{lll}\text { C Additional Results } & \text { A-7 }\end{array}$

C.1 Additional Descriptive Results . . . . . . . . . . . . . . . . . . . A-7

C.2 Further Evidence from the Stimulus in $2008 \ldots \ldots \ldots$. . . . . . . . . . A-7

C.3 Results by Parental Ranks . . . . . . . . . . . . . . . . . . . . . . A-10

C.4 Excluding Infrastructure Expenditure from PGEB $\ldots \ldots \ldots \ldots \ldots$. . . . . . . . .

C.5 Excluding Migrants and Excluding Data in 2005-07 . . . . . . . . . . . A-12

C.6 Additional Evidence from the China Family Panel Studies (CFPS) . . . . . . . A A-13

C.7 PGEB and Government Policy Priority . . . . . . . . . . . . . . A-15 


\section{A CGSS vs. Census Data}

To check the representativeness of CGSS, we report the mean and standard deviation of the key characteristics in CGSS and census, focusing on the urban population. As shown in Table A, CGSS sample is close to being a representative sample of the population. Specifically, the demographic characteristics are comparable between the survey and the census 2010. Because census 2010 does not provide occupations, we turn to the quasi-census 2005 for comparisons. The differences, even though not large, may reflect changes in occupations over time.

Table A: CGSS vs. Census

\begin{tabular}{lccc}
\hline & CGSS 2005-12 & Census 2010 & Quasi-census 2005 \\
\cline { 2 - 4 } College & 0.259 & 0.281 & \\
& $(0.438)$ & $(0.449)$ & \\
Female & 0.504 & 0.495 & \\
Married & $(0.500)$ & $(0.500)$ & \\
& 0.928 & 0.883 & \\
Ethnic minorities & $(0.258)$ & $(0.321)$ & \\
Government job & 0.060 & 0.054 & \\
& $(0.237)$ & $(0.226)$ & 0.253 \\
Business owner & 0.217 & & $(0.435)$ \\
& $(0.412)$ & & 0.013 \\
Self-employed & 0.022 & & $(0.111)$ \\
& $(0.146)$ & & 0.147 \\
& 0.107 & & $(0.354)$ \\
\hline
\end{tabular}

\section{B Understanding PGEB}

\section{B.1 Defining PGEB}

We define PGEB as expenditure on infrastructure and MCF (Manufacturing/Commerce/Finance). All the categories are from China Statistic Yearbooks. In 2007, there is only one broad category of MCF expenditure, which incorporates the related categories in 2005. In later years, the broad definition is divided into more categories again, although with different names. For each category, we refer to the documents from the Ministry of Finance for its definition and sub-categories to make sure our definition is consistent and comparable over years. Our results hold if we exclude infrastructure expenditure from our definition of PGEB, see Appendix Table C.4 for discussion. In 
addition, our main results are also robust to excluding data in 2005 and 2007, as shown in Appendix Table C.5.

We summarize the categories by year in the following table:

Table B.1: Definition of PGEB

\begin{tabular}{lll}
\hline Year & PGEB & $\begin{array}{l}\text { Non-business expenditure } \\
2005\end{array}$ \\
& $\begin{array}{l}\text { Infrastructure } \\
\text { Funds to support firms for } \\
\text { technology innovation and reform } \\
\text { Policy-related subsidies to firms } \\
\text { Sea exploration and subsidies to } \\
\text { FDI and joint-venture firms for land-use } \\
\text { Liquidity funds } \\
\text { Aid to undeveloped regions (fiscal transfer to } \\
\text { promote economic development and infrastructure) }\end{array}$ & $\begin{array}{l}\text { All other categories } \\
\text { (related to public administration, defense, } \\
\text { education, health, and social security) }\end{array}$ \\
& $\begin{array}{l}\text { Transportation } \\
\text { Manufacturing/Commerce/Finance-related } \\
\text { (MCF expend.) }\end{array}$ & $\begin{array}{l}\text { All other categories } \\
\text { (related to public administration, defense, } \\
\text { education, health, and social security) }\end{array}$ \\
& & $\begin{array}{l}\text { The same above + Earthquake relief } \\
\text { and reconstruction (shock in 2008) }\end{array}$ \\
\hline Transportation; Detailed MCF expend. &
\end{tabular}

\section{B.2 PGEB and Firm Subsidy}

Does PGEB reflect government involvement in business? As a check, we examine the correlation between our measure of PGEB and subsidy received by private firms. Specifically, using data from the second National Economic Census (NEC), we find that a one standard deviation increase in PGEB (0.02) is associated with a 0.6 percentage point increased probability of subsidy receipt (column (1) in Table B.2), a very large effect compared to the mean probability (1.3 percentage points). This relationship is robust to introducing firm-level controls (column (2)) and also true at the intensive margin (column (3)). 
Table B.2: Correlations between PGEB and Firm Subsidies in 2008

\begin{tabular}{lccc}
\hline \multirow{3}{*}{ Subsidy } & $(1)$ & $(2)$ & $(3)$ \\
& $0 / 1$ & $0 / 1$ & $\ln (\mathrm{Sub})$, subsidy recipients \\
\cline { 2 - 4 } PGEB & & & \\
& $0.304^{* *}$ & $0.315^{* *}$ & $19.113^{* *}$ \\
ln \#Employee & $(0.148)$ & $(0.150)$ & $(6.958)$ \\
& & $0.004^{* * *}$ & $0.139^{* * *}$ \\
ln Asset & & $(0.001)$ & $(0.027)$ \\
& & $0.002^{* * *}$ & $0.517^{* * *}$ \\
GDP per capita & & $(0.000)$ & $(0.029)$ \\
& & $0.001^{* *}$ & $-0.139 * * *$ \\
& & $(0.001)$ & $(0.033)$ \\
Industry FE & $\mathrm{Y}$ & $\mathrm{Y}$ & $\mathrm{Y}$ \\
Ownership FE & & $\mathrm{Y}$ & $\mathrm{Y}$ \\
Observations & $3,298,048$ & $3,227,381$ & 42,292 \\
R-squared & 0.098 & 0.102 & 0.345 \\
\hline
\end{tabular}

Notes: Standard errors are clustered at the province level. Significance level: ${ }^{*} p<0.1,{ }^{* *} p<0.05,{ }^{* *} p<0.01$.

\section{B.3 PGEB pre-post the Fiscal Stimulus 2008}

In November 2008, as a response to the global financial crisis and the slow-down domestic economy, the Chinese central government announced a fiscal stimulus plan of 4 trillion RMB. Except for the expenditures used in the reconstruction works in the regions destroyed by the 8-magnitude Sichuan earthquake in 2008, $75 \%$ of the package went to business-related expenditure. ${ }^{19}$ As shown in Panel (a) of Figure B.3, the average PGEB was about 2.4 percent (of provincial GDP) prior to the stimulus package and increased to 4.8 percent post the stimulus package. In contrast, Panel (b) shows that the increase in the other fiscal expenditure was modest and statistically insignificant.

${ }^{19}$ For the breakdown of the stimulus package, announced by the National Development and Reform Commission, see: http://www.eeo.com.cn/ens/finance_investment/2009/03/07/131626.shtml. 
Figure B.3: Expenditures pre-post the Stimulus Package

(a) PGEB

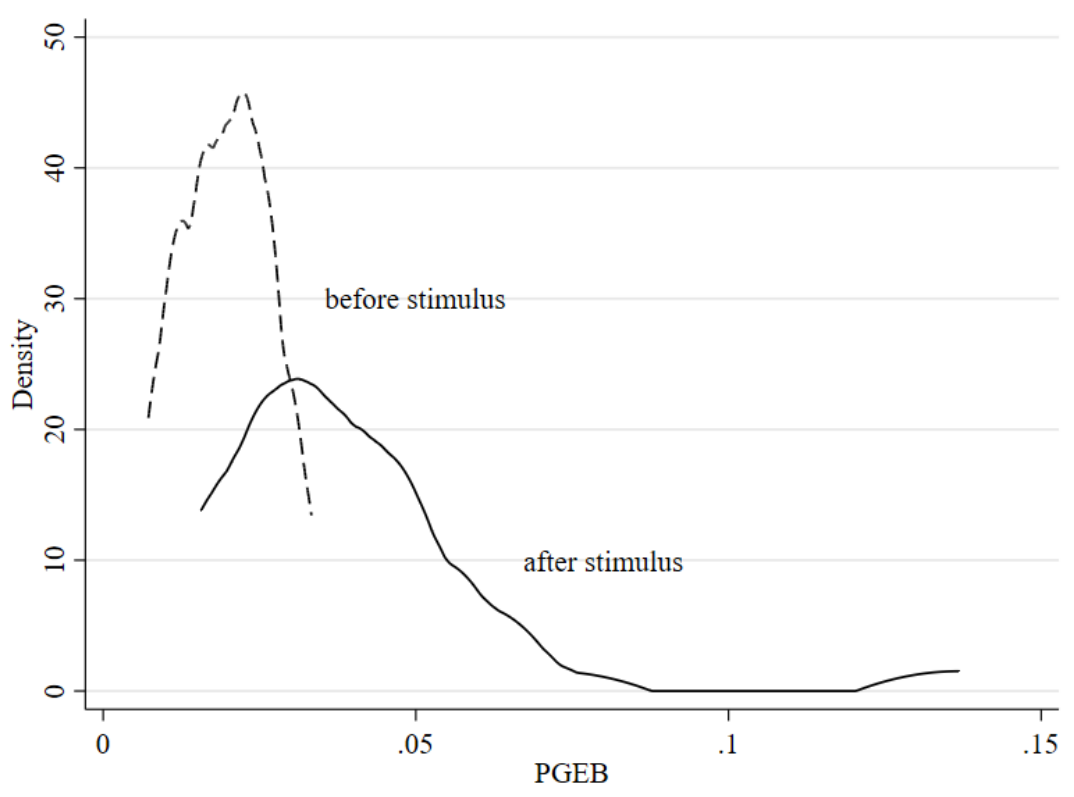

(b) Other expenditures

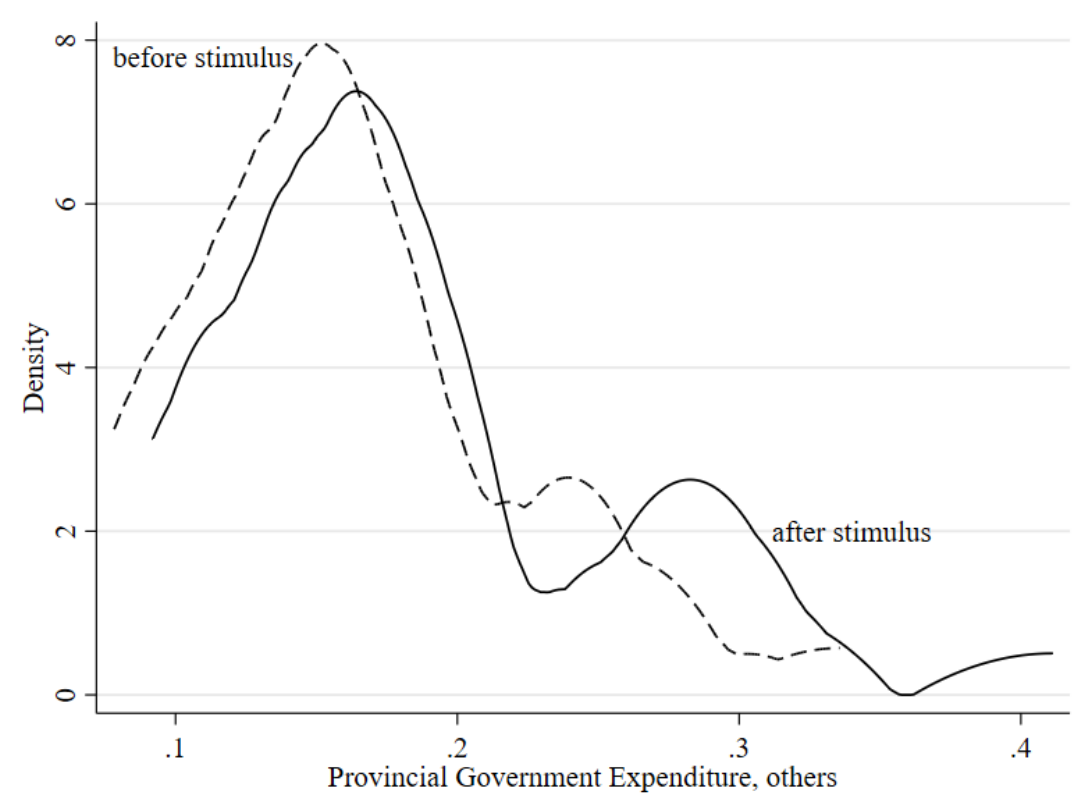




\section{B.4 The Variation in PGEB}

Figure B.4: PGEB vs. SOEs Share and GDP Per Capita across Provinces

(a) PGEB vs. SOEs Share

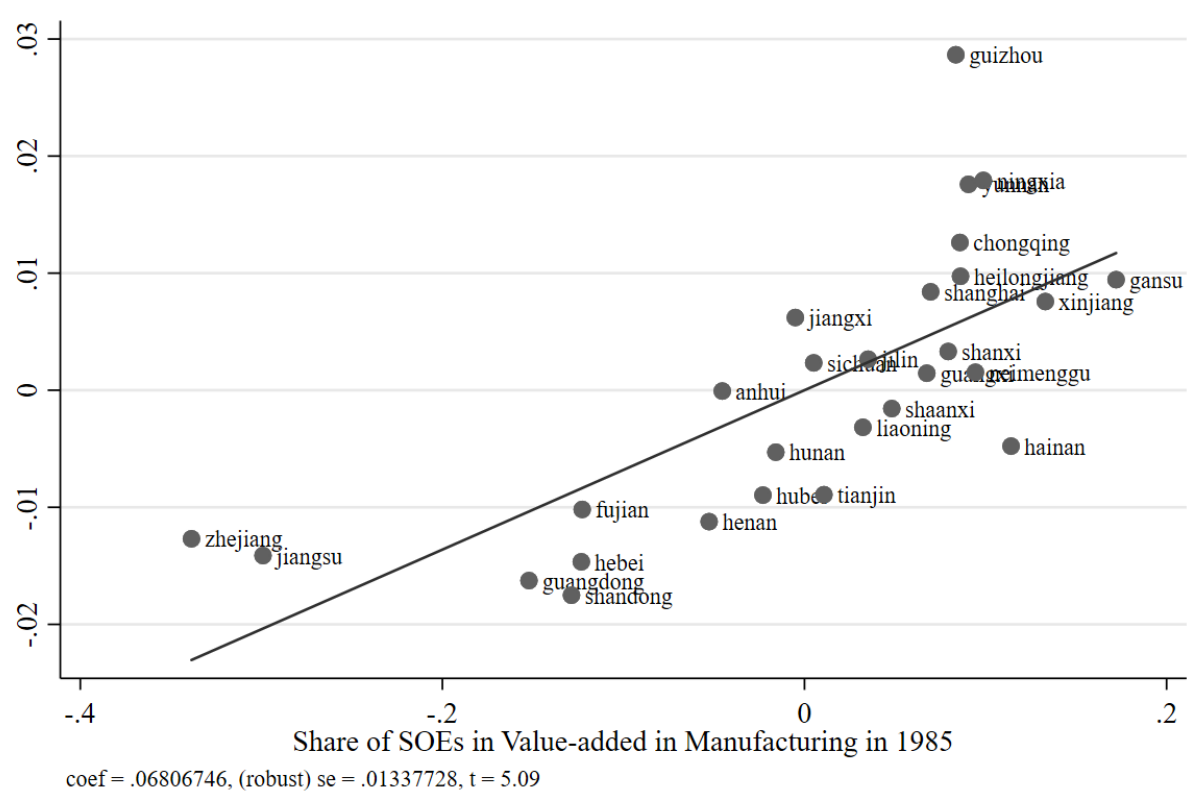

(b) PGEB vs. GDP Per Capita

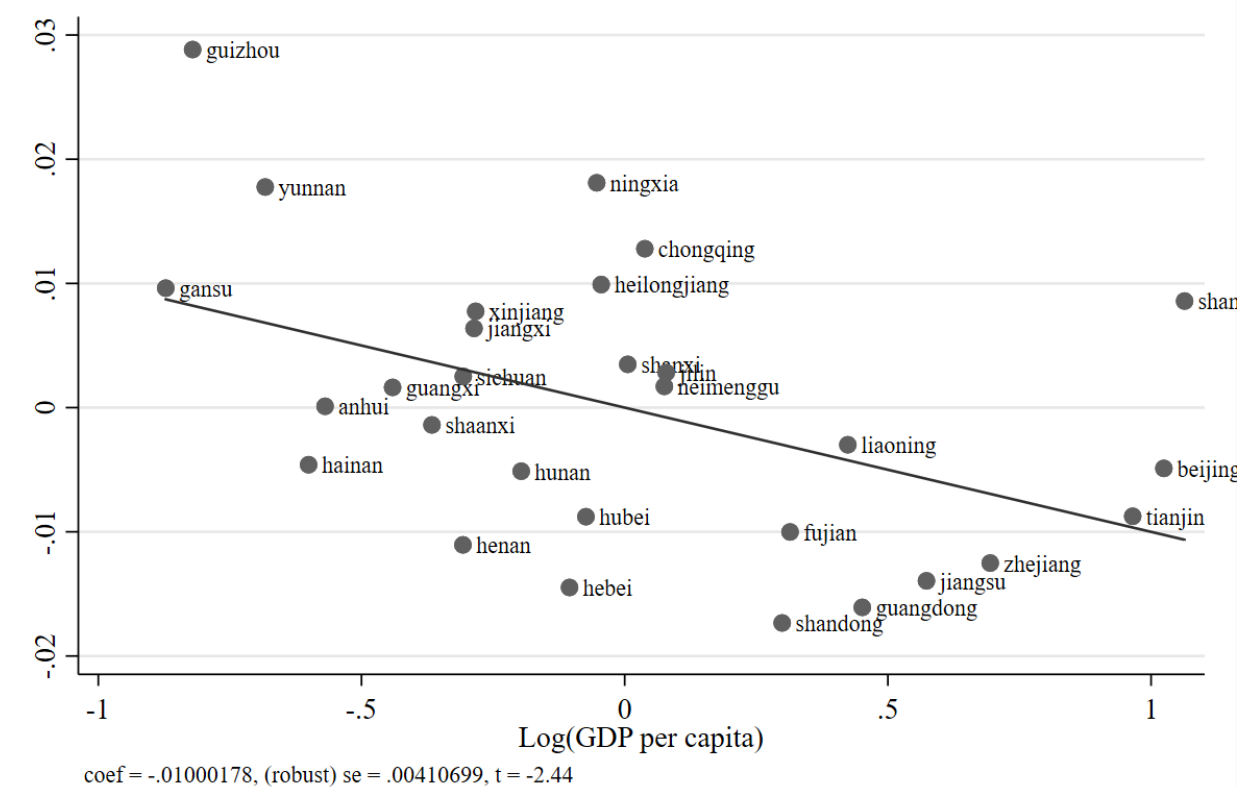


PGEB vs. SOEs Share \& Economic Development. Another fact illustrating that PGEB is a slow-moving provincial characteristics is that $55 \%$ of the cross-provincial variation in PGEB in 2007 is explained by the share of State Owned Enterprises (SOEs) in manufacturing in 1985, presented in Figure B.4(a).

Government involvement in business is negatively correlated with GDP per capita. However, as shown Figure B.4(b) for the cross-province correlation between the average logged GDP per capita and average PGEB in our study period. The R-squared is 0.22 , implying that $22 \%$ of the variation in PGEB can be explained by regional development. As shown, provinces of similar development levels can have different degree of government involvement. For instance, our data confirms the difference in government involvement between Shanghai and Zhejiang mentioned in Huang (2008).

\section{Additional Results}

\section{C.1 Additional Descriptive Results}

The patterns in Figure 1 hold if we focus on non-cadre and non-entrepreneur children as the comparison group, as shown in Figure C.1.

\section{C.2 Further Evidence from the Stimulus in 2008}

Since PGEB is slow-moving, the pre-stimulus PGEB is a good predictor of the post-stimulus expenditure. Specifically, if we regress the post-stimulus PGEB on pre-stimulus PGEB, we obtain a coefficient of 1.869 (with a standard error of 0.173 ) and a $R$-squared of 0.82 . Essentially, this national-level stimulus spending is proportional at provincial level, which provides us useful variation in PGEB. Thus, this policy shock provides us an opportunity to investigate the heterogeneous effect across provinces with the different pre-stimulus level of PGEB.

We divide the provinces into two groups by the median PGEB in the benchmark year of 2005, and examine whether the same policy shock has different impacts across the two groups using a 
Figure C.1: Descriptive Patterns - Different Outcomes vs. PGEB

(a) Diff b/w Cadre Children and Others (Excl. Entrepreneur Children)

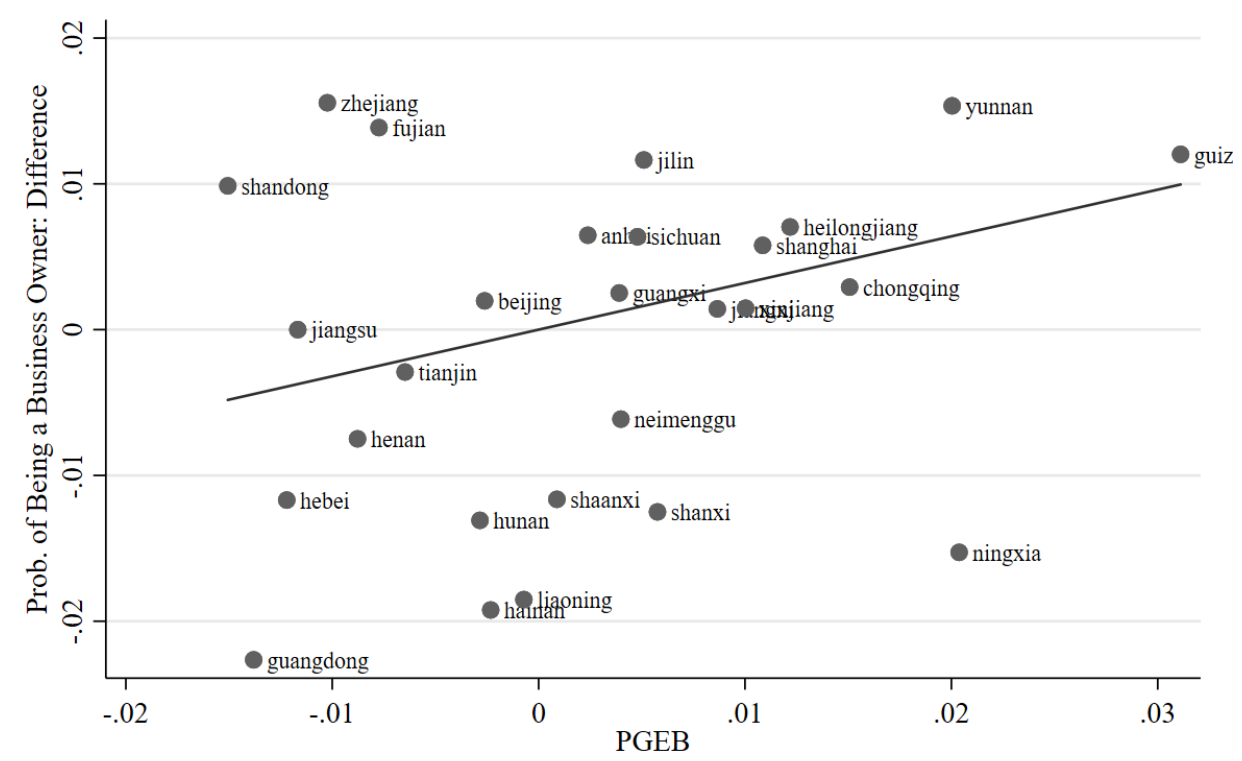

coef $=.32004224$, (robust) $\mathrm{se}=.19985752, \mathrm{t}=1.6$

(b) Diff b/w Entrepreneur Children and Others (Excl. Cadre Children)

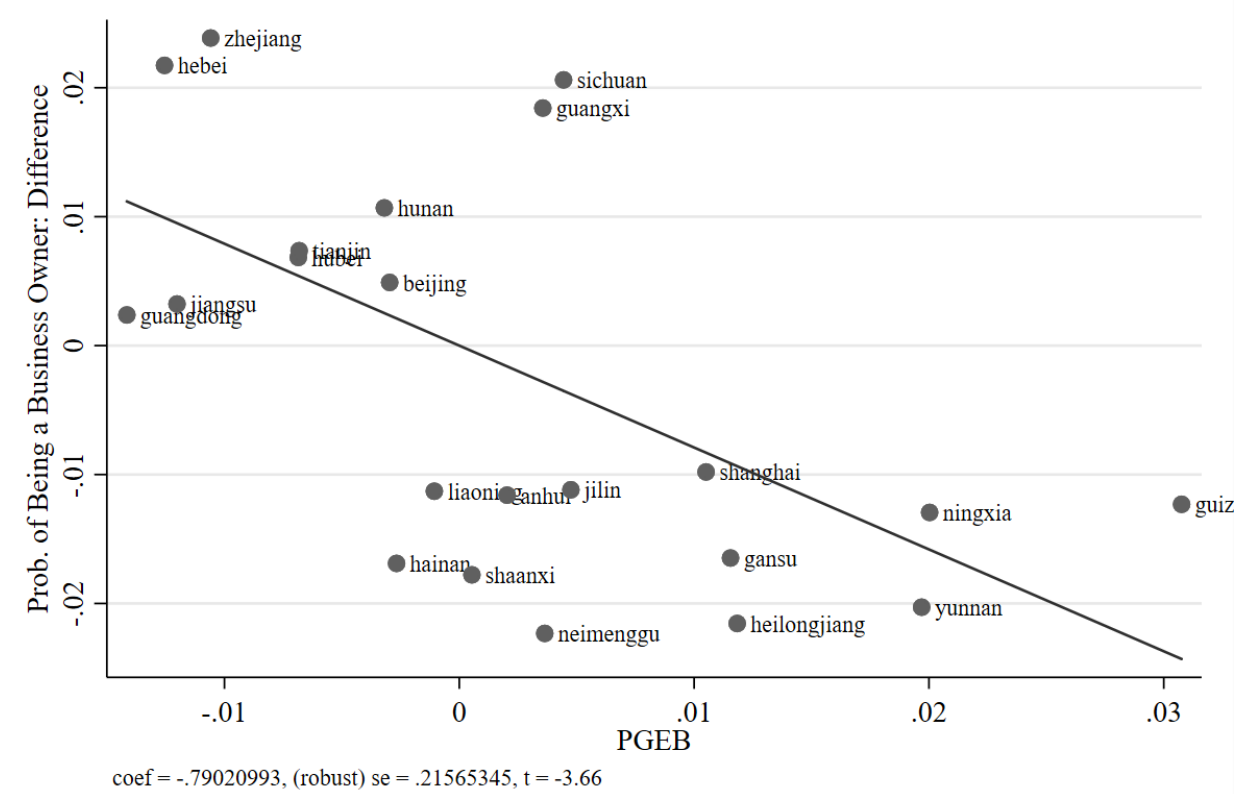


triple difference design as follows:

$$
\begin{aligned}
& \text { Business }_{i, p, t}=\beta_{3} \text { CadreParent }_{i, p, t} \times \text { HighProv }_{p} \times{\text { Post } 08_{t}}_{+}+\beta_{2} \text { CadreParent }_{i, p, t} \times \text { HighProv }_{p}
\end{aligned}
$$

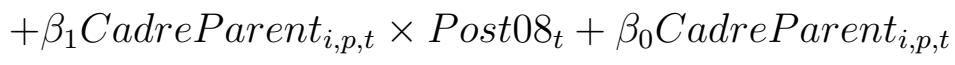

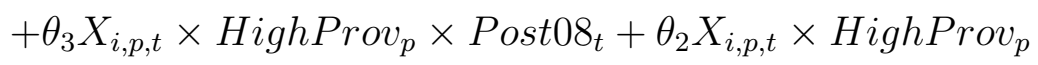

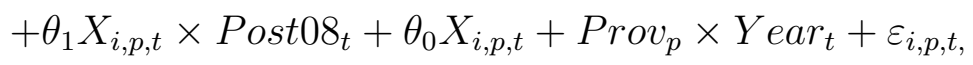

where Post $08_{t}$ is a dummy variable that is 1 for the three waves of the CGSS data in 2009, 2011 and 2012, 0 for the two waves in 2005 and 2007. HighProv indicates whether PGEB was above median in 2005. We also allow for a flexible effect of $X_{i, p, t}$ by interacting it with Post $08_{t}$ and HighProv $_{\text {. }}$

If our earlier hypothesis is correct, we expect to see a positive $\beta_{3}$ because a surge in such fiscal spending encourages people from a cadre family to start a business more in provinces with a higher benchmark PGEB. This is indeed the case, as reported in Table C.2.

Table C.2: Results from the Stimulus Shock

\begin{tabular}{lccccc}
\hline & $(1)$ & $(2)$ & $(3)$ & $(4)$ & $(5)$ \\
& & & & & \\
& & & & Age $<=35$ & Age $>35$ \\
\cline { 2 - 6 } & & & & & \\
Cadre parent $\times$ High benchmark $\times$ Post 2008 & $0.019^{*}$ & $0.019^{*}$ & $0.021^{*}$ & $0.059^{* *}$ & 0.009 \\
& $(0.011)$ & $(0.012)$ & $(0.012)$ & $(0.03)$ & $(0.012)$ \\
Cadre parent & 0.004 & 0.001 & 0.001 & 0.033 & $-0.011^{*}$ \\
& $(0.008)$ & $(0.008)$ & $(0.008)$ & $(0.021)$ & $(0.007)$ \\
Cadre parent $\times$ High benchmark & -0.008 & -0.009 & -0.009 & -0.033 & -0.000 \\
& $(0.010)$ & $(0.010)$ & $(0.010)$ & $(0.027)$ & $(0.011)$ \\
Cadre parent $\times$ Post 2008 & -0.002 & -0.003 & -0.002 & $-0.054^{* *}$ & $0.015^{*}$ \\
& $(0.009)$ & $(0.009)$ & $(0.009)$ & $(0.023)$ & $(0.008)$ \\
Province FE $\times$ Year FE & & & & & \\
Individual characteristics & $\mathrm{Y}$ & $\mathrm{Y}$ & $\mathrm{Y}$ & $\mathrm{Y}$ & $\mathrm{Y}$ \\
Individual char. $\times$ High benchmark $\times$ Post 2008 Y & & & $\mathrm{Y}$ & $\mathrm{Y}$ & $\mathrm{Y}$ \\
including all pairwise interactions) & & & $\mathrm{Y}$ & $\mathrm{Y}$ & $\mathrm{Y}$ \\
Observations & 22,801 & 22,801 & 22,801 & 5,046 & 17,755 \\
R-squared & 0.014 & 0.022 & 0.023 & 0.046 & 0.025 \\
\hline
\end{tabular}

Notes: The individual characteristics include age, gender, ethnic minority status, marriage status, and college education. Standard errors are clustered at the province-year level. Significance level: ${ }^{*} p<0.1, * * p<0.05, * * *<<0.01$.

Compared with the provinces with lower benchmark PGEB, the effect of cadre parents on the probability of being a business owner increases by 1.9 percentage point more after 2008 in the provinces with higher benchmark PGEB, close to the mean probability (0.022). Furthermore, 
this effect is driven by the younger cohort (younger than 35 years old) who are more likely to take advantage of this huge but only one-time shock to change their career. For them, the effect on the probability of being a business owner increases by 5.9 percentage points. In contrast, there is little impact on those aged 35 above.

Thus, the over-time variation in PGEB exhibits the same pattern as the cross-sectional variation. Since the variation we are exploring stems from a national shock which is likely to be exogenous to any specific provincial characteristics, these results provide further support for our main finding.

\section{C.3 Results by Parental Ranks}

There exists heterogeneity among cadres - highly-ranked officials are more powerful than government workers with no ranks. Here, we separate cadre parents by their official ranks (only available in the surveys during 2009-2012) into three groups, using 1 to indicate non-cadre parents. Within the cadre parents, Rank=2 indicates those working in government offices but having no official ranks; Rank=3 indicates those with ranks but ranked below deputy-division-head level; and Rank=4 indicates those ranked at deputy-division-head level and above. To put this into perspective, a Standing Committee member of a county-level Party Committee is ranked at the deputy-division-head level.

While we do not have enough power for each group, we find the impact of CadreParent ${ }_{i} \times$ $P G E B_{p, t}$ increases with ranks, as reported in Appendix Table C.3. Columns (1)-(2) replace the cadre parent dummy with the 1-4 ranks and confirm the positive interaction effect of parental rank and PGEB on children's business ownership. Column (3) reports the results rank by rank. While the estimates are noisy due to the limited power of the survey data, they confirm that the impacts increase with ranks.

\section{C.4 Excluding Infrastructure Expenditure from PGEB}

Our main finding holds if we exclude infrastructure expenditure from PGEB, as reported in Table C.4. 
Table C.3: Results by Parental Official Ranks

\begin{tabular}{|c|c|c|c|}
\hline & (1) & (2) & (3) \\
\hline Parent rank $\times$ PGEB $(\mathrm{sd})$ & $\begin{array}{c}0.004 * * \\
(0.002)\end{array}$ & $\begin{array}{l}0.003 * \\
(0.002)\end{array}$ & \\
\hline Parent rank & $\begin{array}{c}0.003 \\
(0.002)\end{array}$ & $\begin{array}{c}0.003 \\
(0.002)\end{array}$ & \\
\hline Parent rank $(=2) \times$ PGEB $(\mathrm{sd})$ & & & $\begin{array}{c}0.001 \\
(0.004)\end{array}$ \\
\hline Parent rank $(=3) \times$ PGEB $($ sd $)$ & & & $\begin{array}{c}0.006 \\
(0.006)\end{array}$ \\
\hline Parent rank $(=4) \times$ PGEB $(\mathrm{sd})$ & & & $\begin{array}{c}0.015 \\
(0.015)\end{array}$ \\
\hline Parent rank $(=2)$ & & & $\begin{array}{c}0.007 \\
(0.005)\end{array}$ \\
\hline Parent rank (=3) & & & $\begin{array}{c}0.006 \\
(0.007)\end{array}$ \\
\hline Parent rank $(=4)$ & & & $\begin{array}{c}0.007 \\
(0.013)\end{array}$ \\
\hline Entrepreneur parent $\times$ PGEB $(\mathrm{sd})$ & & $\begin{array}{l}-0.008 * \\
(0.004)\end{array}$ & $\begin{array}{l}-0.008 * \\
(0.004)\end{array}$ \\
\hline Entrepreneur parent & & $\begin{array}{c}0.017 * * \\
(0.036)\end{array}$ & $\begin{array}{c}0.017 * * \\
(0.036)\end{array}$ \\
\hline Province $\mathrm{FE} \times$ Year FE & Y & Y & $\mathrm{Y}$ \\
\hline Individual Characteristics & Y & Y & $\mathrm{Y}$ \\
\hline Individual Characteristics $\times$ PGEB & Y & Y & $\mathrm{Y}$ \\
\hline Observations & 14,366 & 14,366 & 14,366 \\
\hline R-squared & 0.021 & 0.022 & 0.022 \\
\hline
\end{tabular}

Notes: The individual characteristics include age, gender, ethnic minority status, marriage status, and college education. Standard errors are clustered at the province-year level. Significance level: ${ }^{*} p<0.1,{ }^{* *} p<0.05, * * *<0.01$. 
Table C.4: Excluding Infrastructure expenditure from PGEB

\begin{tabular}{lccc}
\hline & $(1)$ & $(2)$ & $(3)$ \\
\cline { 2 - 4 } & & & \\
Cadre parent $\times$ MCF $(\mathrm{sd})$ & $0.004^{*}$ & $0.004^{*}$ & $0.005^{* *}$ \\
& $(0.002)$ & $(0.002)$ & $(0.002)$ \\
Cadre parent & $0.006^{* *}$ & 0.002 & 0.002 \\
& $(0.003)$ & $(0.003)$ & $(0.003)$ \\
Entrepreneur parent $\times \mathrm{MCF}(\mathrm{sd})$ & $-0.010^{* *}$ & $-0.010^{* *}$ & $-0.009^{* *}$ \\
& $(0.005)$ & $(0.005)$ & $(0.005)$ \\
Entrepreneur parent & $0.016^{* * *}$ & $0.014^{* *}$ & $0.014^{* *}$ \\
& $(0.006)$ & $(0.006)$ & $(0.006)$ \\
Province FE $\times$ Year FE & & & \\
Individual characteristics & $\mathrm{Y}$ & $\mathrm{Y}$ & $\mathrm{Y}$ \\
Individual characteristics $\times$ MCF expend. & & $\mathrm{Y}$ & $\mathrm{Y}$ \\
Observations & 22,801 & 22,801 & 22,801 \\
R-squared & 0.015 & 0.023 & 0.023 \\
\hline
\end{tabular}

Notes: The individual characteristics include age, gender, ethnic minority status, marriage status, and college education. Standard errors are clustered at the province-year level. Significance level: ${ }^{*} p<0.1, * * p<0.05, * * * p<0.01$.

\section{C.5 Excluding Migrants and Excluding Data in 2005-07}

Our main finding is robust excluding migrants (columns (1)-(2) of Table C.5). It is also robust to using data during 2009-2012, where the PGEB categories remain exactly the same and we can control for county fixed effects (column (3)). 
Table C.5: Excluding Migrants and Excluding Data in 05-07

\begin{tabular}{lccc}
\hline & $(1)$ & $(2)$ & $(3)$ \\
\cline { 2 - 4 } Cadre parent $\times$ PGEB $(\mathrm{sd})$ & $0.005^{*}$ & $0.005^{* *}$ & $0.006^{* *}$ \\
& $(0.002)$ & $(0.002)$ & $(0.002)$ \\
Cadre parent & 0.002 & 0.002 & 0.003 \\
& $(0.003)$ & $(0.003)$ & $(0.003)$ \\
Entrepreneur parent $\times$ PGEB $(\mathrm{sd})$ & $-0.008^{* *}$ & $-0.007^{*}$ & -0.007 \\
& $(0.004)$ & $(0.004)$ & $(0.004)$ \\
Entrepreneur parent & $0.012^{* *}$ & $0.012^{* *}$ & $0.013^{*}$ \\
& $(0.006)$ & $(0.006)$ & $(0.007)$ \\
Province FE $\times$ Year FE & & & \\
Individual characteristics & $\mathrm{Y}$ & $\mathrm{Y}$ & $\mathrm{Y}$ \\
Individual characteristics $\times$ PGEB & & $\mathrm{Y}$ & $\mathrm{Y}$ \\
County FF, 09-12 only & & $\mathrm{Y}$ & $\mathrm{Y}$ \\
Observations & 22,086 & 22,086 & 14,505 \\
R-squared & 0.022 & 0.022 & 0.033 \\
\hline
\end{tabular}

Notes: The individual characteristics include age, gender, ethnic minority status, marriage status, and college education. Standard errors are clustered at the province-year level. Significance level: ${ }^{*} p<0.1, * * p<0.05, * * * p<0.01$.

\section{C.6 Additional Evidence from the China Family Panel Studies (CFPS)}

Replicating CGSS. Can our main result be replicated using other surveys? Here, we employ data from the 2012 wave of the CFPS. The CFPS is a nationally representative, biennial general social survey, launched and conducted in 2010 by the Institute of Social Science Survey (ISSS) of Peking University. It is a panel data over individuals or households. Four waves of the data (2010, 2012, 2014, 2016) have been released to public use. This table uses the individual adult survey in 2012, the first wave that records the occupation of the respondent's parents when the respondent was 14 years old, which is the same as in the CGSS. As in the CGSS, the analysis is restricted to urban respondents in 25 provinces. Since the CFPS is panel data over individuals, the parents' past occupation is fixed across waves, we only employ one wave of the data to corroborate our finding using multiple-wave CGSS data.

Different from CGSS, however, we cannot separate business owners and self-employed using CFPS. Hence, we look at how the probability of becoming an entrepreneur varies by parental background and local context. To compare with CGSS, we normalize the dependent variables by their means. As shown in columns (1)-(4) of Table C.6, the estimated magnitude is close to our main results from the CGSS data: In our main results, one standard deviation increase in PGEB is associated with 25 percent increase in the mean probability of being business owners. In CFPS, one 
standard deviation increase in PGEB is associated with 20 percent increase in the mean probability of being entrepreneurs.

Table C.6: I. Additional Results from CFPS

\begin{tabular}{|c|c|c|c|c|c|c|c|c|}
\hline & (1) & (2) & (3) & (4) & (5) & (6) & (7) & (8) \\
\hline Data & CGSS & CGSS & CFPS & CFPS & CFPS & CFPS & CFPS & CFPS \\
\hline Year & 2005-2012 & 2009-2012 & 2012 & 2012 & 2012 & 2012 & 2012 & 2012 \\
\hline Dependent variable & \multicolumn{2}{|c|}{ Business owner/Mean } & \multicolumn{6}{|c|}{ Entrepreneur/Mean } \\
\hline Cadre parent $\times$ PGEB $(\mathrm{sd})$ & $\begin{array}{c}0.256^{* * *} \\
(0.106)\end{array}$ & $\begin{array}{c}0.245^{* * *} \\
(0.110)\end{array}$ & $\begin{array}{c}0.221 * * \\
(0.100)\end{array}$ & $\begin{array}{c}0.203^{* *} \\
(0.093)\end{array}$ & & & & \\
\hline Cadre parent & $\begin{array}{c}0.075 \\
(0.120)\end{array}$ & $\begin{array}{c}0.077 \\
(0.132)\end{array}$ & $\begin{array}{l}-0.184 \\
(0.151)\end{array}$ & $\begin{array}{l}-0.099 \\
(0.123)\end{array}$ & & & & \\
\hline Risk-love $\times$ PGEB (sd) & & & & & $\begin{array}{l}-0.077 \\
(0.132)\end{array}$ & $\begin{array}{l}-0.097 \\
(0.152)\end{array}$ & & \\
\hline Risk-love & & & & & $\begin{array}{c}0.352 * * * \\
(0.112)\end{array}$ & $\begin{array}{l}0.213^{*} \\
(0.111)\end{array}$ & & \\
\hline Social skill $\times$ PGEB $($ sd) & & & & & & & $\begin{array}{l}-0.015 \\
(0.131)\end{array}$ & $\begin{array}{c}-0.011 \\
(0.138)\end{array}$ \\
\hline Social skill & & & & & & & $\begin{array}{c}0.096 \\
(0.105)\end{array}$ & $\begin{array}{c}0.110 \\
(0.107)\end{array}$ \\
\hline Province FE $\times$ Year FE & $\mathrm{Y}$ & $\mathrm{Y}$ & & & & & & \\
\hline County FE & & Y & $\mathrm{Y}$ & $\mathrm{Y}$ & $\mathrm{Y}$ & $\mathrm{Y}$ & $\mathrm{Y}$ & $\mathrm{Y}$ \\
\hline Individual Characteristics & & & & $\mathrm{Y}$ & & $\mathrm{Y}$ & & $\mathrm{Y}$ \\
\hline Individual Characteristics $\times$ PGEB & & & & $\mathrm{Y}$ & & $\mathrm{Y}$ & & $\mathrm{Y}$ \\
\hline Observations & 22,801 & 15,015 & 6,224 & 6,224 & 2,065 & 2,065 & 4,768 & 4,768 \\
\hline R-squared & 0.022 & 0.032 & 0.071 & 0.088 & 0.106 & 0.131 & 0.075 & 0.094 \\
\hline
\end{tabular}

Notes: The individual characteristics include age, gender, ethnic minority status, marriage status, and college education. Standard errors are clustered at the province-year level. Significance level: ${ }^{*} p<0.1,{ }^{* *} p<0.05$, ${ }^{* * *} p<0.01$.

Risk Attitudes and Social Skills. One advantage of the CPFS is that it contains data on other personal characteristics of respondents, such as risk attitudes and social skills. The question on risk attitudes is asked for individuals with some financial investments. The question is "in your investment portfolio, what type of risks are you willing to take?" The options are (a) "high risk, high return", (b) "moderate risk, steady return", (c) "low risk, low return" and (d) "no risk at all". We define risk-loving if one answers (a) and (b). The results below are robust to using (a) only to define risk-loving. The question on social skills is asked in the family questionnaire. The question is "please self-evaluate how well you get along with people", and the answer ranges from 0-10. We use a dummy indicating being above 5 as higher social skills. The results below are robust to using the value as an alternative definition.

We conduct two sets of analysis. First, we check the correlations between cadre parents and these personal traits and find a very weak correlation, suggesting that cadre children do not differ 
dramatically in these traits. This indicates that it is not likely that the first pattern we uncover is due to cadre parent being a proxy for these other skills/characteristics.

Table C.6: II. Correlations between Cadre Parents and Other Traits

\begin{tabular}{lccc}
\hline & Cadre parent & Risk-love & Social skill \\
\cline { 2 - 4 } Cadre parent & 1.00 & & \\
Risk-love & 0.003 & 1.00 & \\
Social skill & 0.024 & -0.031 & 1.00 \\
\hline
\end{tabular}

Second, we include these additional traits in our analysis. In columns (5)-(6) of Table C.6(I) we show that while a risk-loving attitude is associated with entrepreneurship, it displays no interaction with PGEB. In columns (7) and (8) we show that there is no association between the measure of social skills and entrepreneurship.

Thus, although these individual characteristics can be correlated with entrepreneurship, it is difficult for them to explain the cross-province patterns in our main results.

\section{C.7 PGEB and Government Policy Priority}

To examine how PGEB correlates with government policy priority, we collect text data on annual government reports for the years 2005-2012, where policy priorities are explicitly spelled out. We find that PGEB is negatively correlated with the frequency of private economy mentions (relative to state economy mentions) in government reports (Figure C.7). ${ }^{20}$ This finding is interesting as it dispels the notion that these provinces are trying to catch up in the development of their private sector.

${ }^{20}$ The Chinese words are minying for private economy and guoyou for state economy. 
Figure C.7: PGEB vs. $\ln$ (Word freq: "private")- $\ln$ (Word freq: "state-owned")

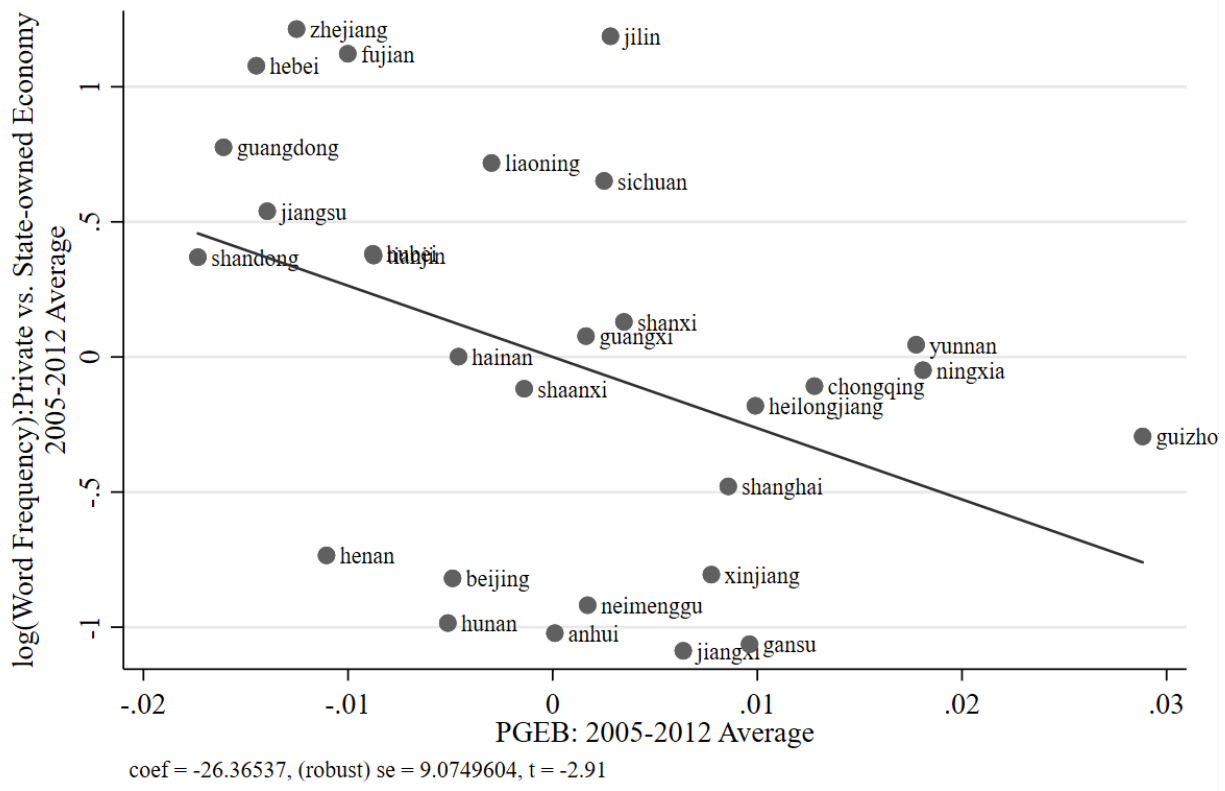

